\title{
Á tilnefningarnefnd að vera undirnefnd stjórnar eða hluthafa? Skoðanir ólíkra hagaðila.
}

\author{
Hildur Magnúsdóttir, Auður Arna Arnardóttir, og Pröstur Olaf Sigur- \\ jónsson ${ }^{1}$.
}

\begin{abstract}
Ágrip
Tilnefningarnefndir eru tiltölulega nýjar sem páttur í stjórnarháttum fyrirtækja á Íslandi, en slík nefnd var fyrst sett á laggirnar árið 2014. Frá peim tíma hafa slíkar nefndir verið að ryðja sér til rúms á Íslandi en pær eiga sér lengri sögu erlendis. Meirihluti skráðra fyrirtækja á Íslandi hefur í dag stofnað tilnefningarnefndir, en pað eru pó skiptar skoðanir um ágæti nefndanna bæði meðal fræðimanna og stjórnenda. Innan Norðurlandanna starfa tilnefningarnefndir ólíkt hvað stjórnarhætti viðkemur, par sem pær heyra ýmist beint undir hluthafa eða eru skipaðar sem undirnefndir stjórna. Hér er um að ræða mikilvægan mun eftir pví hvor leiðin er farin, pví áhrif á meðal annars gagnsæi í starfi nefndanna, valferli vegna nýrra stjórnarmanna og upplýsingagjöf til hluthafa, getur verið ólík eftir pví hvor leiðin er valin. Erlendar rannsóknir á starf tilnefningarnefnda sýna að tilvist peirra getur haft jákvæð áhrif á stjórnarhætti, fyrst og fremst pannig að starf peirra leiði til skilvirks ferlis við val stjórnarmanna. Íslenskar tilnefningarnefndir hafa enn sem komið er lítið verið rannsakaðar. Pessi rannsókn leitast við að varpa ljósi á skoðanir hagaðila um pað hvort tilnefningarnefndir á Íslandi eigi að vera undirnefndir stjórna eða heyra beint undir hluthafa. Blandaðri rannsóknaraðferð er beitt, annars vegar með viðtölum við hluthafa, stjórnarmenn í skráðum fyrirtækjum og nefndarmenn tilnefningarnefnda. Hins vegar er stuðst við niðurstöður könnunar sem send var til hluthafa, stjórnarmanna og tilnefningarnefndarmanna meðal 300 stærstu fyrirtækja á Íslandi. Niðurstöður sýna að hagaðilar telja að tilnefningarnefndir á Íslandi eiga frekar að heyra undir hluthafa en stjórn og pær eiga að vera kosnar af hluthöfum á hluthafafundum. Niðurstöðurnar gagnast hluthöfum og stjórnum fyrirtækja pegar kemur að stofnun og ákvörðun um skipulag í starfi tilnefningarnefnda.
\end{abstract}

\begin{abstract}
Nomination Committees have recently emerged in the context of corporate governance, both in Iceland and other countries; most Icelandic-listed firms have now established them. There are different academic and business world opinions on the committees' rationale, practices, and structure. The committees are operated in different ways within Nordic corporate governance norms, i.e.,
\end{abstract}

1 Hildur Magnúsdóttir er PhD nemi við Háskóla Íslands. Netfang: him14@hi.is. Auður Arna Arnardóttir er dósent við Háskólann í Reykjavík. Netfang: auduraa@ru.is. Pröstur Olaf Sigurjónsson er prófessor við Viðskiptafræðideild Háskóla Îslands. Netfang: olaf@hi.is.

This work is licensed under a Creative Commons Attribution 4.0 License.

DOI: https://doi.org/10.24122/tve.a.2021.18.1.4 
they are either directly subordinate to shareholders or appointed as board subcommittees. Previous research on nomination committees show that their existence can positively affect corporate governance, and that their work can lead to a better process for appointing directors. The committees have not been examined in Iceland before and this research aims to document original insight into their organization. Interviews were conducted with thirteen individuals who are shareholders, board members of listed companies, or committee members. In addition, a questionnaire was sent to shareholders, board members, nomination committee members of the 300 largest companies in Iceland. The findings show that nomination committees in Iceland should be shareholders' committees instead of board sub-committees. Shareholders should also elect the committee members at shareholders' meetings. The results can benefit shareholders and boards when establishing and organizing nomination committees.

JEL flokkun: G30; G34

Lykilorð: Tilnefningarnefndir; stjórnarhættir; undirnefndir, Ísland, Norðurlönd.

Keywords: Nomination Committees; Corporate Governance; Sub-committees, Iceland, Nordic countries.

\section{Inngangur}

Á árinu 2021 eru starfandi 17 tilnefningarnefndir (e. nomination committees) í peim 20 fyrirtækjum sem skráð eru á aðallista íslensks hlutabréfamarkaðar. Ákvæði um tilnefningarnefndir var fyrst sett inn í íslenskar leiðbeiningar um stjórnarhætti árið 2009 (Viðskiptaráð Íslands o.fl., 2009). Með leiðbeiningunum eru fyrirtæki hvött til pess að stofna slíkar nefndir en eru pó ekki skyldug til pess, par sem pau geta valið hvort pau framfylgja leiðbeiningunum eða ekki. Ísland er ekki eina landið sem hefur farið pessa leið en sambærileg ákvæði um tilnefningarnefndir er að finna í stjórnarháttarleiðbeiningum margra annarra landa (sjá til að mynda Committee on Corporate Governance, 2019; NCGB, 2018; Swedish Corporate Governance Board, 2020).

Tilnefningarnefndir eru tiltölulega nýr páttur í stjórnarháttum íslenskra fyrirtækja og hafa lítið verið rannsakaðar hérlendis. Prátt fyrir að ákvæði um tilnefningarnefndir hafi fyrst komið fram í leiðbeiningunum árið 2009, pá var fyrsta nefndin ekki stofnuð fyrr en Sýn hf. stofnaði slíka nefnd árið 2014. Að sögn Páls Harðarsonar, páverandi forstjóra Iceland Nasdaq (2009), var pað pegar bandaríski fjárfestingarsjóðurinn Eaton Vance hóf fjárfestingar á Îslandi og hvatti íslensk fyrirtæki til pess að stofna slíkar nefndir, að meirihluti skráðra fyrirtækja fylgdi í kjölfarið og stofnuðu tilnefningarnefndir. Rök sjóðsins fyrir tilvist tilnefningarnefnda voru fyrst og fremst pau að fagmennska og gagnsæi við val á stjórnarmönnum myndi aukast með tilkomu peirra.

Tilnefningarnefnd er ráðgjafanefnd sem tilnefnir stjórnarmenn til stjórnarsetu sem eru í kjölfarið kosnir af hluthöfum á hluthafafundi félags. Nefndirnar eiga að hafa pað hlutverk að búa til faglegan farveg fyrir framboð til stjórnar fyrirtækis og að leggja mat á hæfni, burði og getu einstaka frambjóðenda til að starfa sem stjórnarmenn og sjá til pess að stjórn sem hópur búi yfir nægilegri breidd til að geta sinnt stefnumarkandi og eftirlitshlutverki stjórnar (Viðskiptaráð Íslands, 2021b). Hugmyndafræðin á bakvið tilnefningarnefndir verður til fyrir ákall um að bæta ferlið við val á stjórnarmönnum (Carlsson, 2007). Áður var ferlið við myndun stjórnar almennt talið óformlegt og ógagnsætt og hvíldi að mestu leyti á herðum forstjóra, stjórnarformanns (Carson, 2002; Sjöstrand o.fl., 2016) eða stærsta hluthafa (Carlsson, 2007). Tilkoma tilnefningarnefnda er talin stuðla annars vegar að faglegra ferli við val á stjórnarmönnum í gegnum rækilega greiningu á færni stjórnarmanna og hins vegar valferlið sjálft (Ruigrok o.fl., 2006).

Til langs tíma hafa tvær tegundir undirnefnda stjórna tíðkast og verið hluti af stjórnar- 
háttum fyrirtækja, en pað eru endurskoðunarnefnd (e. audit committee) og starfskjaranefnd (e. remuneration committee). Tilnefningarnefnd (e. nomination commitee) hefur fylgt í kjölfarið og er yngst hefðbundinna nefnda og er pví ekki eins mikið rannsökuð innan stjórnarhátta og hinar tvær (Huse, 2007; Kaczmarek og Nyuur, 2016). Enn fremur er talsverður breytileiki milli landa hvernig til tilnefningarnefnda er stofnað og hvar nefndin er staðsett í stjórnskipulagi fyrirtækja. Horft til Norðurlandanna, sem oft fylgjast að hvað stjórnarhætti fyrirtækja varðar (Sjöstrand et al, 2016), er að finna breytileika hér. Tafla 1 varpar ljósi á pennan breytileika milli Norðurlandanna. Í Danmörku er tilnefningarnefnd undirnefnd stjórna (Committees on Corporate Governance, 2019) en í Noregi og Svípjóð er um hluthafanefnd að ræða (NCGB, 2018; Swedish Corporate Governance Board, 2020). Í Finnlandi getur verið um bæði að ræða en nefndin er pó kennd við hluthafa (Securities Market Association, 2020). Á Íslandi tíðkast bæði form en ávallt er lokaorð í höndum hluthafa á hluthafafundum. Íslensku leiðbeiningarnar um stjórnarhætti kveða ekki upp úr með petta. Í upplýsingariti um tilnefningarnefndir, sem var gefið út samhliða nýjum leiðbeiningum um stjórnarhætti árið 2021, kemur fram að nefndirnar geti bæði heyrt undir hluthafa eða stjórn (Viðskiptaráð Íslands o.fl., 2021b). Pegar íslensk tilnefningarnefnd er stofnuð er pannig ólíkt hvort um ræðir undirnefnd stjórnar eða hluthafanefnd. Skiptar skoðanir ríkja meðal haghafa hvor leiðin er farsælli (Friðrik Friðriksson, 2019; Porsteinn Friðrik Halldórsson, 2019). Fleiri tengdir pættir eru ólíkir milli landanna eins og hvort meðlimir tilnefningarnefnda megi vera stjórnarmenn eða peir purfi að vera óháðir stjórn fyrirtækis. Enn fremur að hvort pað leyfist að stjórnarmaður sitji í tilnefningarnefnd og hvort stjórnarmenn geti myndað meirihluta tilnefningarnefndar eða ekki.

Álitamálin eru pví nokkur en í pessari rannsókn verður leitast við að fá fram viðhorf hagaðila til pess hvaða form sé skynsamlegt pegar kemur að pví að ákveða hvort tilnefningarnefnd eigi að heyra undir hluthafa eða vera undirnefnd stjórnar. Rýnt verður í kosti og galla sem hagaðilar sjá við hvort formið og enn fremur aðra tengda pætti sem snúa að starfi tilnefningarnefnda, eins og skipan nefndarmanna. Hingað til hefur petta ekki verið rannsakað fyrir íslenskar aðstæður. Á sama tíma er próun á formi tilnefningarnefnda á Íslandi í mikilli gerjun, eins og kemur fram í upplýsingariti Viðskiptaráðs Íslands o.fl. (2021b). Rannsóknarspurningin sem pessi rannsókn svarar er: „Hver eru viðhorf og rök ólíkra haghafa til pess hvort tilnefningarnefnd eigi að vera undirnefnd stjórnar eða hluthafa?“.

Greinin er skipulögð pannig að fyrst er fræðilegt yfirlit par sem gerður er samanburður á pví hvernig skipulagi tilnefningarnefnda er háttað innan stjórnarháttaleiðbeininga á Íslandi og á hinum Norðurlöndunum. Pví næst er aðferðafræði rannsóknarinnar kynnt og pá niðurstöður settar fram. Að endingu eru umræður og lokaorð.

\section{Fræðileg umfjöllun}

\subsection{Stjórnarhættir og stjórnarháttalíkön}

\subsubsection{Stjórnarhættir}

Samkvæmt OECD (2015) er hlutverk stjórnarhátta fyrirtækja að styðja við starfsemi sem einkennist af gagnsæi, áreiðanleika, trausti sem hvetur til fjárfestinga, heiðarlegra viðskiptahátta og fjárhagslegs stöðugleika. Stjórnarhættir eiga pannig að veita fyrirtækjum skipulag og ferla til að starfa eftir skýrri stefnu og að eftirlit sé haft með starfseminni (OECD, 2015). Petta er pó ekki eina skilgreiningin sem finnst á hlutverk stjórnarhátta. Cadbury (2000) skilgreinir stjórnarhætti sem kerfi sem fyrirtækjum er stýrt og stjórnað eftir, á meðan Huse (2007) skilgreinir pá sem samskipti milli ólíkra aðila sem hafa völd innan fyrirtækis eða hagaðila. Pessir ólíku hagaðilar eru samkvæmt Huse (2007) stjórnarmenn og ýmsir ytri og innri aðilar sem stýra fyrirtæki. Innri aðilar eru peir sem taka ákvarðanir eða stýra aðgerðum, t.d. stjórnendur og starfsmenn. Ytri aðilar eru hagaðilar eða peir sem leitast við að stjórna ákvörðunum eða hafa áhrif á eigendur fyrirtækja. Stjórnarmenn eru 
skilgreindir sem sér hópur en ekki er samstaða um hvort peir eigi að flokkast sem innri eða ytri aðilar (Huse, 2007). Рað er í samræmi við skilgreiningu OECD (2015) um að stjórnarhættir fyrirtækja feli í sér samskipti milli hluthafa fyrirtækis, stjórnar, stjórnenda og annarra hagaðila. Stjórnarhættir samkvæmt öðrum skilgreiningum einblína á að finna lausn og í einhverjum tilfellum sérsniðna lausn fyrir hvert fyrirtæki (Thomsen og Conyon, 2019). Pannig geta stjórnarhættir verið sérsniðnir að aðstæðum fyrirtækja (Sjöstrand o.fl., 2016). Stjórnarhættir eru skipulag sem er sett til að tryggja að fyrirtæki séu rekin í págu hluthafa. Hvernig petta skipulag er sett upp fyrir ólík fyrirtæki er vísað til sem stjórnarháttalíkan (e. corporate governance model) (Lekvall, 2014).

\subsubsection{Stjórnarháttalíkön}

Samkvæmt OECD (2015) ættu ólík líkön stjórnarhátta að vera leyfð. Meginreglur um stjórnarhætti sem eru gefnar út af OECD veita sveigjanleg en sterk viðmið til pess. Peir sem nýta viðmiðin geta valið hvaða stjórnarháttalíkan peir styðjast við. Par kemur enn fremur fram að pað sé ekkert eitt líkan stjórnarhátta rétt og að leiðbeiningar og reglur um stjórnarhætti eigi að aðlaga að peim veruleika sem pær búa við (OECD, 2015). Stjórnarháttalíkön hafa í megin atriðum verið skilgreind sem eins-prepa (e. one-tier) og tveggja-prepa (e. two-tier) kerfi en pau eru oft nefnd stjórnarkerfi (e. board system) (Thomsen og Conyon, 2019; Huse, 2007; Lekvall, 2014; Sjöstrand o.fl., 2016). Lekvall (2014) hefur skilgreint priðja líkanið sem hann kallar norræna líkanið (e. Nordic model).

Pessi prjú líkön má sjá á mynd 1. Eins-prepa líkanið er stuðst við í Norður-Ameríku (Lekvall, 2014; Thomsen og Conyon, 2019), Bretlandi, Kína, og Japan (Thomsen og Conyon, 2019), á meðan tveggja-prepa líkanið í Pýskalandi, Danmörku, Noregi og Svípjóð (Thomsen og Conyon, 2019). Norræna líkanið er samkvæmt Lekvall (2014) notað á Norðurlöndunum en pað eru líkindi með pví og tveggja-prepa líkaninu. Í sumum löndum geta fyrirtæki valið hvort líkanið pau styðjast við, eins og t.d.í Danmörku (Thomsen og Conyon, 2019) og Frakklandi (Millet-Reyes og Zhao, 2010; Thomsen og Conyon, 2019). Flest fyrirtæki í Danmörku hafa valið tveggja-prepa líkanið á meðan eins-prepa líkanið er algengara í Frakklandi (Thomsen og Conyon, 2019). Löggjöf hvers lands getur pó haft áhrif hér. Pað er samræmi á milli líkananna að pví leyti að pau eru öll með aðalfund (hluthafafund) efst í stjórnskipulagi sínu sem jafnframt kýs stjórn (Lekvall, 2014; Thomsen og Conyon, 2019). Líkönin eru pó að mörgu leyti ólík og verður nánar greint frá pví hér að neðan.

Mynd 1. Mismunandi stjórnarháttalíkön

Heimild: Lekvall, 2014

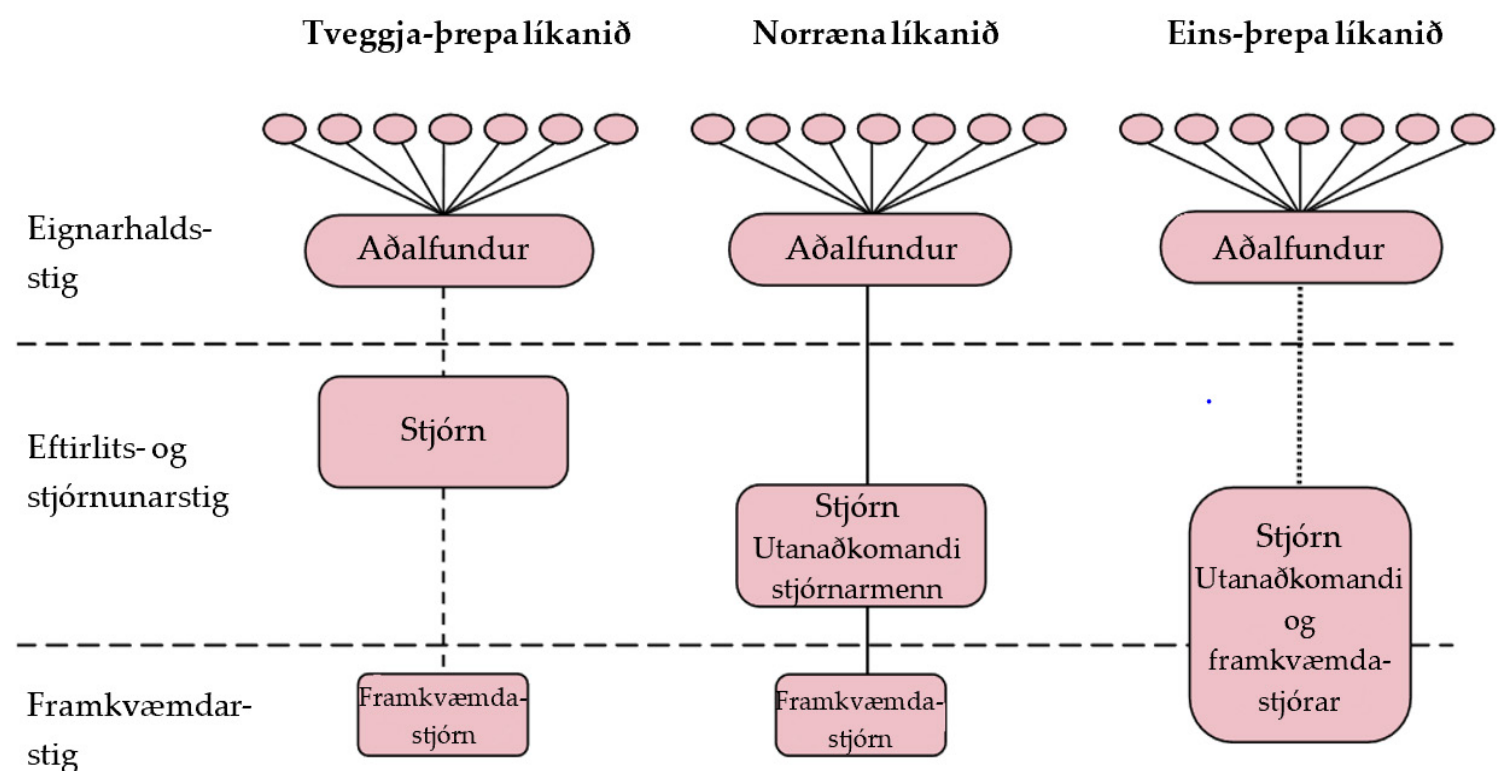


Innan eins-prepa líkansins er stjórn kosin af hluthöfum (Lekvall, 2014; Thomsen og Conyon, 2019). Stjórnin ræður stjórnendur, sem eru annaðhvort valdir úr hópi stjórnarmanna eða utan stjórnar (Thomsen og Conyon, 2019). Раð er aðeins ein stjórn innan eins-prepa líkansins og inniheldur hún bæði aðila úr framkvæmdastjórn (e. executive directors) og utanaðkomandi stjórnarmenn (e. non-executive directors). Stjórnarformaður (e. chair) og forstjóri (e. CEO) er oft sami einstaklingurinn (Lekvall, 2014). Thomsen og Conyon (2019) greina frá pví að flestir stjórnarmenn í Norður-Ameríku og Evrópu séu utanaðkomandi. Flestir utanaðkomandi stjórnarmenn eru óháðir fyrirtæki og eru oft í hlutastarfi (e. parttime) sem stjórnarmenn, pað er peir starfa ekki hjá fyrirtækinu nema pegar peir mæta á stjórnarfundi og aðra fundi tengda stjórnarsetunni (Thomsen og Conyon, 2019). Aðalfundur innan eins-prepa líkansins getur haft meiri völd en innan tveggja-prepa líkansins vegna pess að sá fyrrnefndi getur haft meiri völd yfir stjórninni. Pessi völd geta verið villandi par sem eignarhald er oft dreift, til að mynda geta verið margir fagfjárfestar og/ eða engir meirihluta eigendur í peim löndum sem notast við eins-prepa líkanið. Í peim tilfellum kann að vera erfitt að finna hluthafa sem eru tilbúnir til pess að nýta vald sitt á áhrifaríkan hátt (Lekvall, 2014).

Tveggja-prepa líkanið er við líði í peim löndum par sem lög kveða á um að fyrirtæki skulu hafa tvö stjórnunarstig (Thomsen og Conyon, 2019). Innan pessa líkans er stjórn (e. supervisory board) kosin af hluthöfum en hún á að hafa eftirlit og yfirumsjón með framkvæmdastjórn (e. management board) (Lekvall, 2014; Thomsen og Conyon, 2019). Stjórn er eftirlitsaðili og er aðskilin framkvæmdastjórn, sem hefur nánast allt framkvæmdavald (Lekvall, 2014). Stjórnarmenn sitja ekki í framkvæmdastjórn. Í sumum tilvikum getur minnihluti stjórnar verið skipaður aðilum úr framkvæmdastjórn (Thomsen og Conyon, 2019). Samkvæmt Lekvall (2014) er pó ekki hægt að sitja í báðum stjórnum samtímis. Völd stjórnar eru pví takmörkuð pegar pessu líkani er beitt, en stjórn getur alltaf sagt upp framkvæmdastjóra og ráðið nýjan, ef ástæður eru til. Stjórnin hefur vald til pess að hafna tillögum framkvæmdastjórnar en í peim tilfellum geta stjórnendur leitað til hluthafafundar sem tekur endanlega ákvörðun. Hluthafar hafa samt sem áður takmarkað vald innan pessa líkans til pess hafa áhrif á stjórnun fyrirtækis (Lekvall, 2014). Í tveggja-prepa líkaninu er pað ekki hlutverk stjórnar að stýra fyrirtæki heldur er pað í verkahring framkvæmdastjórnar. Stjórn hefur ávallt pað hlutverk að sampykkja allar meiriháttar ákvarðanir (Thomsen og Conyon, 2019).

Samkvæmt Lekvall (2014) er norræna líkanið nátengt tveggja-prepa líkaninu og er oft flokkað sem slíkt (Thomsen og Conyon, 2019). Líkanið sem notað er í Svípjóð hefur oft verið lýst sem líkani par sem skipting á ábyrgð og hlutverkum milli mismunandi stiga er skýr og pað aðgreini líkanið frá öðrum (Carlsson, 2007). Samkvæmt Lekvall (2014) er norræna líkanið frábrugðið eins- og tveggja-prepa líkönunum á prjá vegu og er pað rakið hér að neðan. Í fyrsta lagi telur Lekvall (2014) að prátt fyrir að hluthafar kjósi stjórn á aðalfundi innan allra líkananna pá séu pað atkvæði meirihlutans sem hafa endanlegt vald innan norræna líkansins. Stigveldið er skýrt, stjórnin heyrir undir hluthafafund og framkvæmdastjórn heyrir undir stjórn. Samkvæmt Lekvall (2014) er skýr stjórnlína (e. chain of command) innan norræna líkansins (eins og sýnt er með óbrotinni línu á mynd 1) milli prepanna, sem táknar strangari stigveldisskipan en í öðrum líkönum. Annar pátturinn samkvæmt Lekvall (2014) er að hluthafarnir skipa stjórnina, sem er ábyrg gagnvart hluthöfum og er veitt umboð til pess að stjórna fyrirtækinu. Aftur á móti geta hluthafar vikið stjórnarmönnum frá hvenær sem er á kjörtímabilinu, án ástæðu, en pað getur tryggt að stjórnarmenn víki fyrir meirihluta eigendum eða meirihluta aðalfundar (Lekvall, 2014). Íslensk löggjöf kveður á um að hluthafafundur geti hvenær sem er vikið frá stjórnarmönnum og kosið nýja stjórn (Lög um hlutafélög, nr. 2/1995). Í priðja lagi felst munurinn á milli norræna líkansins og annarra líkana samkvæmt Lekvall (2014) í pví að pað er greinileg aðgreining á milli framkvæmdastjórnar og stjórnar. Stjórnin getur ráðið og sagt upp stjórnendum hvenær sem er. Innan tveggja-prepa líkansins er punktalína milli mismunandi 
prepa en innan norræna líkansins er óbrotin lína. Lekvall (2014) fullyrðir að pessi óbrotna lína sýni að pað sé strangt stigveldi á milli prepa. Punktalínan í öðrum líkönum sýni á sama tíma að pað er takmarkað stjórnunarvald á milli prepa. Ráðandi hluthöfum innan norræna líkansins eru veittar víðtækar heimildir til pess að sjá til pess að fyrirtæki sé stýrt eins og hentar. Hluthafar hafa vald bæði yfir stjórn og framkvæmdastjórn á meðan hluthafar innan tveggja-prepa líkansins eru með takmarkaðar valdheimildir yfir stjórnendum (Lekvall, 2014).

Norðurlöndin eru samt sem áður talin vera með mismunandi afbrigði af norræna líkaninu (Lekvall, 2014). Sjöstrand o.fl. (2016) hafa pó komist að peirri niðurstöður að líkindin á milli landanna vegi pyngra en pað sem er ólíkt. Á Norðurlöndunum er regluverkið líkt, bæði pað sem kallast mjúk og hörð löggjöf. Enn fremur hafa hluthafar á Norðurlöndum sambærilegt ákvörðunarvald og dreifing valds er svipuð. Munurinn er talinn minniháttar en par sem hann birist snýr hann að mestu að lögum og reglum landanna. Til dæmis hefur pað áhrif á hvernig stjórn er skipuð og samsett og ef prepið fyrir neðan stjórnina á að vera með framkvæmdastjórn eða einn framkvæmdastjóra. Samkvæmt Sjöstrand o.fl. (2016) veitir norræna líkanið fyrirtækjum sveigjanleika til pess að búa til sínar eigin lausnir. Stjórnarhættir geta pannig verið sérsniðnir til að henta hverju fyrirtæki. Pessi sveigjanleiki er talinn einn helsti styrkleiki norræna líkansins par sem fyrirtæki purfa ekki að framfylgja stöðluðum lausnum sem purfa að taka mið af ólíku eignarhaldi og félagsformi. Sjöstrand o.fl. (2016) telja að petta geri kerfinu kleift að próast og aðlagast með eðlilegum hætti.

\subsection{Tilnefningarnefndir}

Leiðbeiningar um stjórnarhætti (e. corporate governance codes) fara gjarnan fram á eða leggja til að stór fyrirtæki stofni undirnefndir stjórna (Huse, 2007). Að skipa undirnefnd getur beint athygli að sérstökum páttum starfseminnar, sem kann að vera ein leið til pess gera starf stjórnar markvisst. Undirnefndir eru venjulega skipaðar stjórnarmönnum en ekki stjórnendum eða öðrum starfsmönnum. Рað teldist ekki til góðra stjórnarhátta að stjórnendur eða starfsmenn geti til að mynda haft áhrif á eigin kjör í gegnum starfskjaranefndir eða hvernig eftirliti með peim er háttað (Thomsen og Conyon, 2019). Undirnefndir eru taldar geta aukið virði fyrirtækja, sér í lagi peirra sem hafa fjölmennari stjórnir og par sem óháðir stjórnendur eru í meirihluta. Í minni stjórnum og pegar innherjar eru ráđandi innan stjórna er talið að undirnefndir geri ekki eins mikið gagn (Reeb og Upadhyay, 2010). Prjár nefndir eru algengastar, en рað eru endurskoðunarnefnd, starfskjaranefnd og tilnefningarnefnd (Huse, 2007).

Pessar prjár tegundir nefnda hafa verið rannsakaðar á síðustu árum en tilnefningarnefnd pó lang minnst (Huse, 2007; Kaczmarek og Nyuur, 2016; Ruigrok o.fl., 2006). Tilnefningarnefnd er yngst pessara priggja nefnda en samkvæmt Huse (2007) hefur hún verið umdeild innan stjórnarhátta. Prátt fyrir pað er í leiðbeiningum um stjórnarhætti mælt með pví að fyrirtæki stofni slíka nefnd (Huse, 2007) eins og sjá má í leiðbeiningum um stjórnarhætti á Norðurlöndunum (t.d., Committee on Corporate Governance, 2019; Securities Market Association, 2020; Swedish Corporate Governance Board, 2020). Íslensku leiðbeiningarnar um stjórnarhætti eru par engin undantekning (Viðskiptaráð Íslands o.fl., 2021a) og hafa tilnefningarnefndir verið hluti af leiðbeiningunum frá pví árið 2009 (Viðskiptaráð Íslands o.fl., 2009).

\subsubsection{Stofnun tilnefningarnefnda}

Pað er skýr valdalína innan stjórnarhátta sem nær yfir prjár stoðir stjórnskipulags fyrirtækis. Pær prjár eru aðalfundur, stjórn og framkvæmdastjórn, eins og er skilgreint í tveggjaprepa og norræna líkaninu. Ýmsar nefndir eru tengdar mismunandi stoðum stjórnskipulagsins en tilnefningarnefndir, sem einbeita sér að vali á stjórnarmönnum og samsetningu stjórnar, eru sagðar ein mikilvægasta nefndin innan ferla stjórnarhátta á Norðurlöndunum 
(Sjöstrand o.fl., 2016). Tilnefningarnefndir komu til síðar en endurskoðunar- og starfskjaranefndir og eru par af leiðandi ekki eins proskaðar (Carson, 2002) og hafa verið minna rannsakaðar (Kaczmarek o.fl., 2012).

Leiðbeiningar um stjórnarhætti hvetja fyrirtæki til pess að stofna tilnefningarnefndir til pess að tryggja faglegt ferli við leit og val á stjórnarmönnum (Carlsson, 2007). •að eru pó engar lagalegar kröfur á fyrirtæki að stofna slíkar nefndir (Sjöstrand o.fl., 2016). Áður en tilnefningarnefndir komu fram hafði ferlið við myndun stjórna í för með sér að hluthafar báru ábyrgð á pví að tilnefna og kjósa stjórn (Carlsson, 2007). Forstjóri eða stjórnarformaður gegndu oft lykilhlutverki við val á nýjum stjórnarmönnum (Carson, 2002; Sjöstrand o.fl., 2016). Раð аð hluthafar tilnefni stjórnarmenn getur samkvæmt Thomsen og Conyon (2019) haft áhrif á gæði stjórna ef hluthafar hafa ekki nægar upplýsingar eða nauðsynlega pekkingu sem parf til pess að skipa hæfa stjórnarmenn (Thomsen og Conyon, 2019). Áður en tilnefningarnefndir komu til var ferlið í Svípjóð pannig að leiðandi eigandi og stjórnarformaður söfnuðu saman stærstu hluthöfum sem höfðu samanlagt meirihluta atkvæðisréttar, til að ræða endurnýjun stjórnar. Ferlið hófst yfirleitt með samtölum premur til sex mánuðum fyrir aðalfund og peir frambjóðendur sem hluthafar voru sammála um voru að pví loknu tilnefndir á aðalfundi (Carlsson, 2007). Pegar tilnefningarnefndir eru ekki til staðar í íslenskum fyrirtækjum er pað oft í verkahring stjórnarformanns að finna stjórnarmenn en stærsti hluthafinn kemur gjarnan að ferlinu, sem oft gerist óformlega (Sjöstrand o.fl., 2016). En hluthafar kjósa á aðalfundi um samsetningu næstu stjórnar (Viðskiptaráð o.fl., 2021).

Hluthafar skipa stjórnarmenn á aðalfundi og pað er á ábyrgð hluthafa að ákveða hvernig ferlinu er háttað, pað er peir geta stofnað tilnefningarnefnd til að sjá um ferlið. Reglur um skipan tilnefningarnefnda eru yfirleitt mótaðar af leiðbeiningum um stjórnarhætti par sem ekki eru til staðar lagalegar kröfur um pær (Sjöstrand o.fl., 2016). Ef ákveðið er að stofna tilnefningarnefnd getur ferlið við val nýrra stjórnarmanna verið ákvarðað af samsetningu hluthafahópsins (Carson, 2002; Ruigrok o.fl., 2016; Sjöstrand o.fl., 2016). Раð getur til að mynda haft mikil áhrif á val nýrra stjórnarmanna ef pað er einn mjög stór hluthafi innan hluthafahópsins. Par er ólíklegra að fyrirtæki með einn stóran hluthafa stofni tilnefningarnefnd (Ruigrok o.fl., 2006).

Tilnefningarnefndir gegna mikilvægu hlutverki innan stjórnarhátta pegar ekki eru til staðar ráðandi hluthafar og eignarhaldið er dreifðara (Sjöstrand o.fl., 2016). Stór fyrirtæki eru líklegri til pess að stofna tilnefningarnefndir (Carson, 2002; Ruigrok o.fl., 2006). Ef fyrirtæki er með ráðandi eða einn stóran hluthafa (e. main shareholder) getur pað dregið úr mikilvægi pess að stofna tilnefningarnefnd par sem samsetning stjórnar er oft ákvörðuð af ráðandi hluthafa (Sjöstrand o.fl., 2016). Ef fyrirtæki er með tvo eða fleiri stóra hluthafa (e. significant shareholder), verður umræðan um samsetningu stjórnar oft óformleg og fer ekki fram á fundum með tilnefningarnefnd. Í pessum tilvikum er hlutverk tilnefningarnefnda að staðfesta og formlega fara yfir tillögur hluthafa. Í pessum tilvikum hafa nefndirnar takmörkuð áhrif á útkomuna og eru oft og tíðum aðeins stofnaðar til pess að uppfylla kröfur sem settar eru í leiðbeiningum um stjórnarhætti (Sjöstrand o.fl., 2016). Рað getur haft áhrif hvort fyrirtæki eru með óháða og utanaðkomandi stjórnarmenn, en fyrirtæki sem eru með marga óháða stjórnarmenn eru líklegri til pess að starfrækja tilnefningarnefndir (Ruigrok o.fl., 2006).

Að stofna sérstaka tilnefningarnefnd getur haft ákveðna kosti í för með sér við tilnefningar stjórnarmanna. Par má helst nefna að nefndin einbeitir sér að pví að meta mögulega frambjóðendur par sem önnur stjórnarmál eru ekki að hafa truflandi áhrif, eins og til dæmis mál sem rædd eru á stjórnarfundum (Hutchinson o.fl., 2015). Carson (2002) komst аð pví að sum fyrirtæki telja að tilnefningarnefndir hafi takmarkað gildi ef skilningurinn er sá að nefndirnar aðeins einblíni á að velja nýja stjórnarmenn en meti ekki frammistöðu stjórnar. Leiðbeiningar um stjórnarhætti á Norðurlöndunum eru með leiðbeiningar fyrir 
starf tilnefningarnefnda. Pær fela ekki í sér lagalegar kröfur heldur er í peim svokölluð „fylgið eða skýrið“ (e. comply or explain) regla. Рað pýðir að fyrirtæki geti ákveðið að fylgja leiðbeiningunum eða skýra út hvernig vikið er frá peim (Committee on Corporate Governance, 2019; Viðskiptaráo Íslands o.fl., 2021a; NCGB, 2018; Swedish Corporate Governance Board, 2020). Fyrirtæki geta pví innleitt leiðbeiningarnar að fullu eða ákveðið að víkja frá peim að einhverju leyti. Stjórn skal pó gera ítarlega grein fyrir öllum frávikum og að hvaða leyti leiðbeiningunum er ekki fylgt (Viðskiptaráð Íslands o.fl., 2021a). Í uppfærðum leiðbeiningum Viðskiptaráðs frá 2021, er ítrekað að tilnefningarnefnd geti heyrt annaðhvort undir stjórn eða hluthafa, en að hluthafar skuli skipa nefndina og ákveði hvernig nefndin skuli skipuð. Jafnframt er kveðið á um í upplýsingariti um tilnefningarnefndir að misjafnt sé hvort nefndirnar sem pegar hafa verið stofnaðar hér á landi heyri undir stjórn eða hluthafa. Meirihluti nefndanna séu pó hluthafanefndir en tvær nefndir eru aðeins skipaðar stjórnarmönnum og eru pá jafnframt undirnefnd stjórnar (Viðskiptaráð Íslands o.fl., 2021b).

\subsubsection{Skipulag tilnefningarnefnda}

Tilnefningarnefndir gegna mikilvægu hlutverki og samkvæmt Zhang (2008) er óhæði peirra mikilvægt. Samkvæmt bandarískum rannsóknum á tilnefningarnefndum getur tilkoma nefndanna dregið úr peim áhrifum sem forstjórar hafa á valferli stjórnarmanna. Shivdasani og Yermack (1999) telja pó аð раð аð hafa tilnefningarnefnd færi aðeins vandamálið til, pað er að forstjóri reyni að hafa áhrif á tilnefningarnefnd í stað stjórnar. Раð er misjafnt á milli landa og stjórnskipulags hvernig tilnefningarnefndir eru stofnaðar og hverja hún starfar fyrir, fyrir hluthafa eða sem undirnefnd stjórnar. Í Svípjóð er pað á ábyrgð aðalfundar að skipa tilnefningarnefnd. Nefndin heyrir undir og er ábyrg gagnvart aðalfundi og er hún eingöngu skipuð fulltrúum eigenda (Carlsson, 2007). Tilnefningarnefndir ásamt endurskoðunar- og starfskjaranefndunum eru í ýmsum rannsóknum sagðar vera undirnefndir stjórnar (Appiah og Chizema, 2015; Carson, 2002; Kaczmarek o.fl., 2012; Ruigrok o.fl., 2006). Lekvall (2014) heldur pví pó fram að undirnefndir stjórna á Norðurlöndum eigi aðeins að vera skipaðar stjórnarmönnum og stjórnin í heild beri ábyrgð á starfsemi peirra.

Niðurstöður rannsóknar á skráðum félögum í Norður-Ameríku, par sem eins-prepa líkanið er notað, sýna að tilnefningarnefndir eru að fullu óháðar ef "gráir" stjórnarmenn (e. grey directors), forstjórinn og undirmenn peirra eiga ekki sæti í nefndinni og taka ekki pátt í tilnefningarferlinu. Óhæði nefndarinnar er mikilvægt par sem eftirlit með stjórninni er betra ef bæði nefndin og stjórnin eru óháð (Guo og Masulis, 2015). Óháð tilnefningarnefnd getur betur ákvarðað samsetningu peirra sem eru líklegir til pess að vera skipaðir í stjórnina (Eminet og Guedri, 2010).

Ruigrok o.fl. (2006) komust að pví við rannsókn á skráđum fyrirtækjum í Sviss að tilnefningarnefndir eru oft nefndir utan stjórnar (e. „off-board“ committee). Prátt fyrir pað telja peir að nefndirnar séu tæknilega undirnefnd stjórnar par sem ákvarðanir peirra purfa að vera staðfestar af stjórn. Hún sé pannig ekki sjálfstæð nefnd sem heyri beint undir hluthafa á aðalfundi. Í Svípjóð hafa samtökin Small Shareholders Association verið á móti pví að fylgja engilsaksneskri aðferð um að tilnefningarnefnd heyri undir stjórn. Carlsson (2007) staðhæfir að pannig skipulag brjóti í bága við meginreglur um stjórnarhætti fyrirtækja. Hann segir að pörf sé á pví að nefndin sé yfir stjórn í stjórnskipulagi (Carlsson, 2007). Aðrar rannsóknir í Svípjóð sýna að tilnefningarnefndir geta gert minni hluthöfum kleift að koma sínum sjónarmiðum á framfæri en nefndunum er ætla að vera vettvangur fyrir hluthafa til að beita samstöðureglu (e. consensus principle). Tilnefningarnefnd er kosin á aðalfundum en með pví geta minni hluthafar haft áhrif á niðurstöðurnar. Stórir hluthafar ná pó yfirleitt yfirburðarstöðu í nefndinni sýna sumar rannsóknir (Poulsen o.fl., 2010). 
Tafla 1. Skipulag tilnefndinganefnda á Norðurlöndum

\begin{tabular}{|c|c|c|c|c|c|}
\hline & Ísland & Danmörk & Finnland & Noregur & Svípjóð \\
\hline $\begin{array}{l}\text { Hluthafanefnd } \\
\text { eða undirnefnd } \\
\text { stjórnar }\end{array}$ & Hluthafar ákveði & $\begin{array}{l}\text { Undirnefnd } \\
\text { stjórnar }\end{array}$ & $\begin{array}{l}\text { Annaðhvort } \\
\text { hluthafanefnd } \\
\text { eða undirnefnd } \\
\text { stjórnar }\end{array}$ & Hluthafanefnd & Hluthafanefnd \\
\hline $\begin{array}{l}\text { Fjöldi tilnefning- } \\
\text { ar-nefndarmanna }\end{array}$ & $\begin{array}{l}\text { Að lágmarki prír } \\
\text { nefndarmenn } \\
\text { eða tveir ef báđir } \\
\text { eru óháðir }\end{array}$ & $\begin{array}{l}\text { Fjöldi nefndar- } \\
\text { manna kemur } \\
\text { ekki fram í leið- } \\
\text { beiningum }\end{array}$ & $\begin{array}{l}\text { Að lágmarki prír } \\
\text { nefndarmenn ef } \\
\text { nefndin heyrir } \\
\text { undir stjórn, } \\
\text { engin fyrirmæli } \\
\text { um fjölda ef } \\
\text { nefndin heyrir } \\
\text { undir hluthafa }\end{array}$ & $\begin{array}{l}\text { Fjöldi nefndar- } \\
\text { manna kemur } \\
\text { ekki fram í leið- } \\
\text { beiningum }\end{array}$ & $\begin{array}{l}\text { Að lágmarki prír } \\
\text { nefndarmenn }\end{array}$ \\
\hline $\begin{array}{l}\text { Stjórnarmenn i til- } \\
\text { nefningar-nefnd }\end{array}$ & $\begin{array}{l}\text { Stjórnarmenn } \\
\text { geta átt sæti í } \\
\text { nefndinni ef peir } \\
\text { eru ekki meiri- } \\
\text { hluti nefndar- } \\
\text { manna }\end{array}$ & $\begin{array}{l}\text { Stjórnarmenn } \\
\text { geta átt sæti i til- } \\
\text { nefningar- nefnd }\end{array}$ & Valkvætt & $\begin{array}{l}\text { Aðeins einn } \\
\text { stjórnarmaður } \\
\text { má sitja í nefnd- } \\
\text { inni á hverjum } \\
\text { tíma og aðeins } \\
\text { ef hann er ekki } \\
\text { í endurkjöri til } \\
\text { stjórnar }\end{array}$ & $\begin{array}{l}\text { Stjórnarmenn } \\
\text { geta átt sæti í } \\
\text { nefndinni ef peir } \\
\text { eru ekki meiri- } \\
\text { hluti nefndar- } \\
\text { manna }\end{array}$ \\
\hline $\begin{array}{l}\text { Óháđir nefndar- } \\
\text { menn }\end{array}$ & $\begin{array}{l}\text { Meirihluti óháð- } \\
\text { ur fyrirtækinu og } \\
\text { daglegum stjórn- } \\
\text { endum }\end{array}$ & $\begin{array}{l}\text { Meirihluti } \\
\text { óháður }\end{array}$ & $\begin{array}{l}\text { Meirihluti óháð- } \\
\text { ur fyrirtækinu }\end{array}$ & $\begin{array}{l}\text { Meirihluti } \\
\text { óháður stjórn og } \\
\text { framkvæmda- } \\
\text { stjóra }\end{array}$ & $\begin{array}{l}\text { Meirihluti óhád- } \\
\text { ur fyrirtækinu og } \\
\text { að lágmarki einn } \\
\text { nefndarmaður } \\
\text { skal vera óháður } \\
\text { stærsta hluthaf- } \\
\text { anum }\end{array}$ \\
\hline Heimild: & $\begin{array}{l}\text { (Viðskiptarád Ís- } \\
\text { lands o.fl., 2021). }\end{array}$ & $\begin{array}{l}\text { (Committee on } \\
\text { Corporate Go- } \\
\text { vernance, 2019). }\end{array}$ & $\begin{array}{l}\text { (Securities Mar- } \\
\text { ket Association, } \\
\text { 2020). }\end{array}$ & (NCGB, 2018). & $\begin{array}{l}\text { (Swedish Corpo- } \\
\text { rate Governance } \\
\text { Board, 2020). }\end{array}$ \\
\hline
\end{tabular}

Рað er munur á milli Norðurlandanna hvernig tilnefningarnefndir eru skipaðar eins og sjá má í töflu 1. Í Svípjóð og Noregi kjósa aðalfundir meðlimi nefndanna eða ákveða meginreglur um pað hvernig pær eru skipaðar. Nefndirnar eru ekki undirnefndir stjórnar í pessum tveimur löndum (Sjöstrand o.fl., 2016). Sænskar tilnefningarnefndir eru hluthafanefndir (Poulsen o.fl., 2010). Hluthafar eiga sjálfir að skipa tilnefningarnefndarmenn (Swedish Corporate Governance Board, 2020; Poulsen, 2010). I Noregi eru nefndirnar einnig hluthafanefndir og tilnefningarnefndarmenn eru kosnir af hluthöfum á hluthafafundi (NCGB, 2018). Tilnefningar til stjórnarsetu í Danmörku eru á ábyrgð stjórnar (Sjöstrand o.fl., 2016). Tilnefningarnefndir eru samkvæmt leiðbeiningum par í landi undirnefndir stjórna. Pær eru stofnaðar af stjórn og eiga að sinna vinnu sem stjórnir taka ákvarðanir út frá. Meirihluti meðlima nefnda skulu vera óháðir. •að kemur ekki fram í leiðbeiningunum hvort nefndirnar eigi aðeins að vera skipaðar stjórnarmönnum, eins og kveðið er á um hvað varðar endurskoðunarnefndir (Committee on Corporate Governance, 2019).

Í Finnlandi er val um hvort nefndirnar eigi að vera undirnefndir stjórna eða hluthafanefndir. Ef nefndin er hluthafanefnd kallast hún „Shareholders' Nomination Board“ (Securities Market Association, 2020). Á undanförnum árum hafa tveir priðju tilnefningarnefnda í Finnlandi verið undirnefndir stjórna, en einn priðji skipaður sem hluthafanefndir (Sjöstrand o.fl., 2016). Tilnefningarnefnd sem undirnefnd skal stofnuð af stjórn og skipuð stjórnarmönnum, en kveðið er á um að meirihluti nefndarmanna eigi að vera óháður fyrirtækinu. Tilnefningarnefnd sem undirnefnd hluthafa, skipuð af aðalfundi, samanstendur annaðhvort af stærstu hluthöfum eða einstaklingum sem peir tilnefna, hvort sem peir eiga 
sæti í stjórn eða ekki. Leiðbeiningarnar taka ekki fram hvor aðferðin er talin heppilegri kostur. Meirihluti nefndarmanna í báðum nefndum ætti pó að vera óháður fyrirtækinu og einstaklingar úr framkvæmdastjórn eiga ekki að vera skipaðir í nefndina (Securities Market Association, 2020).

Íslensku leiðbeiningarnar um stjórnarhætti kveða ekki á um pað hvort tilnefningarnefndir eigi að vera undirnefndir stjórnar eða heyra beint undir hluthafa. Aðeins er kveðið á um að hluthafar eigi að ákveða hvernig nefndirnar eru skipaðar (Viðskiptaráð Íslands o.fl., 2021). Pegar tilnefningarnefndir urðu fyrst hluti af leiðbeiningum um stjórnarhætti á Íslandi var kaflinn um pær settur fram sem undirkafli í kaflanum um undirnefndir stjórna. Par kom fram að stjórn getur tekið ákvörðun um pað hvort slík nefnd er stofnuð eða ekki (Viðskiptaráð Íslands, o.fl., 2009). Pegar leiðbeiningarnar voru uppfærðar árið 2012 voru tilnefningarnefndir enn skilgreindar sem undirnefnd stjórnar en áttu pó að taka til hagsmuna allra hluthafa (Viðskiptaráð Íslands o.fl., 2012). Pegar leiðbeiningarnar voru gefnar út árið 2015 var gerð sú breyting að kaflinn um tilnefningarnefndir var færður og settur undir kaflann um hluthafa og hluthafafund (Viðskiptaráð Íslands o.fl., 2015). Раð var enn fremur útskýrt að tilnefningarnefndir ættu að vera undir hluthöfum en ekki sem undirnefnd stjórnar, eins og fyrri leiðbeiningar höfðu mælst til (Viðskiptaráð Íslands o.fl., e.d.). Samkvæmt útgefnu riti Ólafs Arinbjarnar Sigurðssonar (e.d.), lögmanni hjá LOGOS, útilokar pessi breyting pað ekki að nefndirnar geti verið undirnefndir stjórnar par sem hluthafar eiga að stofna nefndina og geti pannig ákveðið hvort hún sé undirnefnd stjórnar eða heyri undir hluthafa. Helstu breytingar á leiðbeiningunum sem komu út árið 2021 eru fyrst og fremst hvað umfjöllun um tilnefningarnefndir varðar, en enn fremur er skerpt á ákvæðum um óhæði stjórnarmanna, að stjórn fyrirtækis ætti að setja stefnu á sviði sjálfbærni svo og ýta undir fjölbreytileika í samsetningu stjórnar, framkvæmdastjórnar og meðal stjórnenda almennt og að endingu að stjórn ætti að birta yfirlit ófjárhagslegra upplýsinga (Viðskiptaráð, 2021a).

Erlendar rannsóknir sýna аð pað er misjafnt milli landa hvort að tilnefningarnefndir eru skipaðar sem undirnefnd stjórnar eða hvort pær heyri beint undir hluthafa (t.d. Poulsen o.fl., 2010; Sjöstrand o.fl., 2016). Nefndirnar eru tiltölulega nýtilkomnar á Íslandi og pví er mikilvægt að fanga sýn ólíkra haghafa á pví hvernig pær eiga að vera skipaðar innan íslenskra stjórnarhátta og rök ólíkra haghafa fyrir skoðun sinni. Til pess að varpa ljósi á pað hvernig best sé að haga skipun tilnefningarnefnda á Íslandi var sett fram rannsóknarspurning og leitast við að svara hvort nefndirnar eiga að heyra undir hluthafa eða vera undirnefnd stjórnar að mati ólíkra haghafa.

\section{Aðferð}

Til pess að fá betri innsýn í hlutverk, skipulag og starfshætti tilnefningarnefnda á Íslandi var notast við blandaða rannsóknaraðferð, par sem samtímis var beitt eigindlegri og megindlegri nálgun í rannsókninni (e. Convergent Parallel Mixed Methods Design. Sjá Johnson o.fl, 2007). Viðtölum var annarsvegar beitt og hins vegar var gögnum aflað með spurningakönnun. Viðtöl voru tekin við tilnefningarnefndarmenn, stjórnarmenn, hluthafa og ráðgjafa með раð аð markmiði að fá upplýsingar um mismunandi hlutverk, skipulag og starfshætti nefndanna. Að bví loknu var spurningakönnun send út til pess að fá fram viðhorf frá fleiri hluthöfum, stjórnarmönnum og tilnefningarnefndarmönnum. Niðurstöður beggja nálgana voru svo bornar saman til að kanna samhljóm í garð rannsóknarspurningar, og er pað stuðst við lýsandi tölfræði og pema greiningu í orðræðu

\subsection{Eigindleg aðferd}

Við gagnaöflun var notast við hálf-staðlaðan viðtalsramma. Раð var gert til pess að geta, par sem раð var talið pjóna tilgangi rannsóknarinnar, spurt frekar út í atriði sem fram komu í viðtölunum og kafa dýpra í efnið (Merriam, 2016). Viðtalsramminn var búinn til eftir fjölda funda milli rannsakenda og ítarlega skoðun á viðfangsefninu en ekki var 
hægt að finna einn viðtalsramma frá fyrri rannsóknum sem hentaði pessari rannsókn. Hluti spurninganna var pó fenginn úr rannsókn Clune o.fl. (2016) en aðrar spurningar voru settar saman að vel ígrunduðu máli. Rannsakendur sátu lokaða vinnustofu pann 17. janúar 2020 er nefndist „,tölum um tilnefningarnefndir" og haldin var á vegum Viðskiptaráðs Íslands par sem ýmis atriði varðandi skipulag og starfshætti voru rædd. Umræða pess fundar hafði áhrif á viðtalsrammann en auk pess var rætt við hluthafa og reynda tilnefningarnefndarmenn er viðtalsrammi var útbúinn.

Viðtalsramminn skiptist í prjá hluta. Fyrsti hlutinn innihélt bakgrunnsspurningar og spurningar um hvaða reynslu viðmælendur hefðu af starfsemi tilnefningarnefnda. Næsti hluti snéri að stofnun og skipulagi tilnefningarnefnda. Voru viðmælendur meðal annars spurðir að pví hvernig væri farsælast að skipa nefndina og undir hverja hún ætti að heyra. Að auki var spurt um tilkomu nefndanna og ávinning af pví að starfrækja slíkar nefndir. Priðji hlutinn snéri að starfsemi nefndanna sjálfra (nánari útlistun á heildar innihaldi viðtalsramma má sjá í Hildur Magnúsdóttir, 2020).

Til að ná sem bestum skilningi var rætt við tilnefningarnefndarmenn, stjórnarmenn skráðra félaga og fjárfesta. Viðmælendur voru valdir eftir fyrrnefndan fund hjá Viðskiptaráði, út frá reynslu af starfi nefndanna og opinberri umræðu um pær. Viðtölin, sem voru að meðaltali 63 mínútur að lengd, fóru flest fram í febrúar og mars 2020 fyrir utan tvö viðtöl sem voru tekin í gegnum fjarfundarbúnað í júní 2020. Haft var samband við viðmælendur með tölvupósti par sem markmið rannsóknarinnar var kynnt. Í upphafi hvers viðtals var skipulag viðtalsrammans kynnt og beðið um leyfi til að taka viðtölin upp. Allir viðmælendur fyrir utan einn sampykktu upptöku, en í pví viðtali var heimilt að skrifa niður minnispunkta. Trúnaði og nafnleysi viðmælenda var gætt. Yfirlit yfir viðmælendur og hlutverk peirra má sjá í töflu 2. Viðmælendum var gefið númer og tölustafi sem vísa í pað hvort peir eru tilnefningarnefndarmenn („, $\left.\mathrm{T}^{\prime \prime}\right)$, stjórnarmenn (,S), bæði stjórnar- og tilnefningarnefndarmenn („T-S“), fulltrúar fjárfesta („, $\left.\mathrm{F}^{\prime \prime}\right)$ eða ráðgjafar („,R“).

Viðtölin, par sem pað var heimilt, voru tekin upp og afrituð í kjölfarið. Í framhaldinu var grunduð kenning notuð til pess að greina gögnin með kerfisbundnum hætti. Að pví loknu var leitast við að próa kenningu út frá gögnunum (Strauss og Corbin, 1998). Afrituðu gögnin voru pví næst kóðuð. Notast var við opna kóðun sem felur í sér að mikilvæg atriði eða frasar eru merkt og er gert til pess að greina gögnin frekar (Merriam, 2016). Gögnin voru kóðuð með pví að nota forritið NVivo par sem pemu og undirflokkar voru skilgreindir eftir eðli spurninga og flokkun meginraka viðmælenda. Öll viðtöl voru kóðuð af einum rannsakanda og yfirfarin af tveimur meðrannsakendum til gæta að innra réttmæti kóðunar.

Tafla 2. Viðmælendur í eigindlegri rannsókn

\begin{tabular}{lll}
\hline Viðmælandi & Kyn & Hlutverk \\
\hline 1.T & Kona & Tilnefningarnefnd \\
3.T & Kona & Tilnefningarnefnd \\
4.T & Kona & Tilnefningarnefnd \\
5.T & Kona & Tilnefningarnefnd \\
6.T & Karl & Tilnefningarnefnd \\
7.T & Kona & Tilnefningarnefnd \\
8.T-S & Kona & Tilnefningarnefnd, stjórn og ráðgjafi \\
9.T-S & Karl & Tilnefningarnefnd og stjórn \\
10.S & Karl & Tilnefningarnefnd og stjórn \\
11.F & Karl & Stjórn \\
12.F & Kona & Stofnanafjárfestir \\
13.R & Karl & Stofnanafjárfestir \\
\hline
\end{tabular}




\subsection{Megindleg aðferð}

Megindlegum gögnum var safnað til pess að ná til eins margra hluthafa, stjórnarmanna í skráðum félögum og tilnefningarnefndarmanna eins og hægt var. Spurningarlistinn var settur saman eftir að meirihluti viðtalanna hafði farið fram. Við gerð spurningalistans var horft til sömu sjónarmiða og pegar viðtalsramminn var settur saman en auk pess var einnig horft til pess sem fram kom í viðtölunum.

Viðskiptaráð Íslands hafði áformað að senda út spurningalista um leiðbeiningar í stjórnarháttum. Í mars 2020 sátu rannsakendur fund með starfsmönnum Viðskiptaráðs og var ákveðið að sameina pessa tvo spurningarlista. Pegar spurningarlistarnir voru tilbúnir voru Outcome Kannanir ráðnir af Viðskiptaráði til pess að sjá um framkvæmd gagnaöflunar en könnunin var send út af Viðskiptaráði Íslands. Spurningalistanum var skipt í fjóra hluta. Fyrsti hlutinn voru bakgrunnsspurningar varðandi aldur, kyn, menntun og hvort pátttakendur væru tilnefningarnefndarmenn, stjórnarmenn og/eða hluthafar. Næsti hluti innihélt spurningar frá Viðskiptaráði um leiðbeiningar um stjórnarhætti. Priðji hlutinn var um tilnefningarnefndirnar sjálfar, hvernig pær ættu að vera skipaðar, hverjir eiga að sitja í nefndunum og hversu ánægðir pátttakendur eru með nefndirnar. Síðasti hlutinn var aðeins fyrir pá sem hafa átt sæti í tilnefningarnefndum og snéri að starfsemi nefndanna, .

Könnunin var send til alls 542 einstaklinga. Alls tóku 138 pátt og var svarhlutfall pví 25\%. Viðskiptaráð hafði aðgang að stórum hluta netfanga tilnefningarnefndarmanna, stjórnarmanna, hluthafa og fulltrúa 300 stærstu fyrirtækja á Íslandi. Auk pess söfnuðu rannsakendur hluta af netföngunum fyrir tilnefningarnefndarmenn og stjórnarmenn. Pátttakendum var skipt í fjóra hópa, eins og sjá má í töflu 3 hér fyrir neðan. Fyrsti hópurinn eru hluthafar, bæði stofnanafjárfestar og einkafjárfestar. Næsti hópur eru stjórnarmenn í skráðum félögum og priðji hópurinn eru tilnefningarnefndarmenn, bæði peir sem sátu í nefndum pegar könnunin var framkvæmd eða höfðu áður átt sæti í slíkri nefnd. Fjórði og síðasti hópurinn eru peir sem eru í stjórnum óskráđra félaga, eru ekki tilnefningarnefndarmenn og ekki hluthafar. Eins og sjá má í töflu 4, pá voru 66\% pátttakenda karlkyns og $63 \%$ pátttakenda voru 50 ára eða eldri.

Tafla 3. Pátttakendur í spurningakönnun

\begin{tabular}{lcc}
\hline Hlutverk pátttakenda & Fjöldi & $\%$ \\
\hline Tilnefningarnefnd & 20 & $14 \%$ \\
Stjórn skráðra félaga & 16 & $12 \%$ \\
Hluthafar & 62 & $45 \%$ \\
Aðrir & 40 & $29 \%$ \\
\hline
\end{tabular}

Tafla 4. Pátttakendur í spurningakönnun: kyn og aldur

\begin{tabular}{lcc}
\hline Kyn pátttakenda & Fjöldi & $\%$ \\
\hline Kona & 46 & $33 \%$ \\
Maður & 91 & $66 \%$ \\
Annað/óskilgreint & 1 & $1 \%$ \\
\hline Aldur pátttakenda & Fjöldi & $\%$ \\
\hline 30-39 ára & 16 & $12 \%$ \\
$40-49$ ára & 36 & $26 \%$ \\
$50-59$ ára & 55 & $40 \%$ \\
60 ára eða eldri & 31 & $23 \%$ \\
\hline
\end{tabular}




\section{Niðurstöður}

Niðurstöður eru birtar með peim hætti að fyrst er greint frá niðurstöðum úr spurningakönnuninni og í kjölfarið er gerð nánari grein fyrir rökum sem fram komu við greiningu viðtala. Niðurstöðurnar varpa ljósi á pað hver viðhorf ólíkra haghafa eru til pess hvernig æskilegt er að skipuleggja tilnefningarnefndir innan stjórnarhátta skráðra félaga á Íslandi.

Lista yfir íslensk skráð fyrirtæki árið 2020, og hver peirra hafa stofnað tilnefningarnefnd, má sjá í töflu 5. Alls höfðu sextán af tuttugu félögum sem eru skráđ í íslensku kauphöllina í ágúst 2020 stofnað tilnefningarnefndir, en í júlí 2021 eru eins og áður kom fram nefndirnar orðnar 17. Í peim öllum sitja prír nefndarmenn en mismunandi er hvort stjórnarmenn eiga par sæti eða ekki. Í alls sjö félögum er tilnefningarnefnd að fullu skipuð utanaðkomandi aðilum, í sjö félögum á einn stjórnarmaður sæti í tilnefningarnefnd á móti tveimur utanaðkomandi óháðum aðilum (Hildur Magnúsdóttir, 2020). Tvær nefndir eru að fullu skipaðar stjórnarmönnum, en pær eru báðar skipaðar sem undirnefndir stjórnar (Eimskipafélag Íslands hf., 2020; Marel, 2019). Fjögur skráð félög höfðu ekki tilnefningarnefnd árið 2020. Ljóst er pví að breytileiki í nálgun er mikill meðal íslenskra skráðra fyrirtækja í dag.

Tafla 5. Tilnefningarnefndir á Íslandi árið 2020

Heimild: Hildur Magnúsdóttir, 2020.

\begin{tabular}{|c|c|c|}
\hline Fyrirtæki & Tilnefningarnefnd & $\begin{array}{l}\text { Fjöldi stjórnarmanna í } \\
\text { tilnefningarnefnd }\end{array}$ \\
\hline Arion Banki hf. & Já & 1 \\
\hline Brim hf. & Nei & \\
\hline Eik fasteignafélag hf. & Já & 0 \\
\hline Eimskipafélag Íslands hf. & Já & 3 \\
\hline Festi hf. & Já & 1 \\
\hline Hagar hf. & Já & 0 \\
\hline Heimavellir hf. & Nei & \\
\hline Iceland Seafood International hf. & Nei & \\
\hline Icelandair Group hf. & Já & 1 \\
\hline Kvika banki hf. & Nei & \\
\hline Marel hf. & Já & 3 \\
\hline Origo hf. & Já & 1 \\
\hline Reginn hf. & Já & 0 \\
\hline Reitir fasteignafélag hf. & Já & 0 \\
\hline Síminn hf. & Já & 0 \\
\hline Sjóvá-Almennar tryggingar hf. & Já & 0 \\
\hline Skeljungur hf. & Já & 1 \\
\hline Sýn hf. & Já & 1 \\
\hline Tryggingamiðstöðin hf. & Já & 1 \\
\hline Vátryggingafélag Íslands hf. & Já & 0 \\
\hline
\end{tabular}

\subsection{Viðhorf ólíkra haghafa}

Pegar pátttakendur í spurningakönnun voru spurðir hvort tilnefningarnefndir ættu að heyra undir hluthafa eða stjórn kom í ljós að 65\% pátttakenda telja að nefndin eigi að heyra undir hluthafa. Aftur á móti telja $14 \%$ pátttakenda að nefndirnar eigi að vera undirnefndir stjórnar og 14\% telja að pær eigi að heyra bæði undir stjórn og hluthafa. Niðurstöður má sjá á mynd 2 hér á eftir. 
Mynd 2. Undir hverja eiga tilnefningarnefndir að heyra?

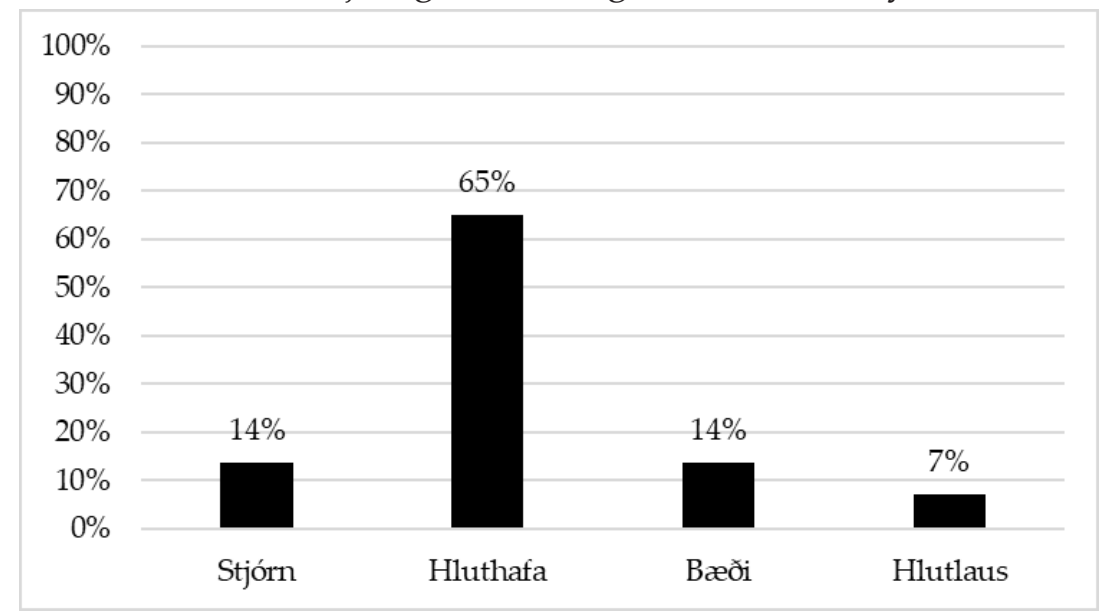

Pegar niðurstöðurnar voru skoðaðar eftir mismunandi haghafa hópum kom í ljós að ekki var mikill munur á milli hópa eins og sjá má í töflu 6 . Yfir $60 \%$ hluthafa, tilnefningarnefndarmanna og stjórnarmanna telja að nefndin eigi að heyra undir hluthafa. Á meðan telja 55\% af peim sem heyra undir flokkinn "Aðrir" að nefndirnar eigi að heyra undir hluthafa. Mikill meiri hluti tilnefningarnefndarmanna telja að nefndin eigi að heyra undir hluthafa, eða $85 \%$.

Tafla 6. Undir hverja eiga tilnefningarnefndir að heyra? Niðurstöður eftir hópum.

\begin{tabular}{lccccc}
\hline Nefndin á að heyra undir: & Stjórn & Hluthafa & Bæði & Hlutlaus & Samtals \\
\hline Tilnefningarnefndarmenn & 1 & 17 & 2 & 0 & 20 \\
$\%$ & $5 \%$ & $85 \%$ & $10 \%$ & $0 \%$ & $100 \%$ \\
Stjórnarmenn & 4 & 10 & 1 & 1 & 16 \\
$\%$ & $25 \%$ & $63 \%$ & $6 \%$ & $6 \%$ & $100 \%$ \\
Hluthafar & 8 & 41 & 9 & 4 & 62 \\
$\%$ & $13 \%$ & $66 \%$ & $15 \%$ & $6 \%$ & $100 \%$ \\
Aðrir & 6 & 22 & 7 & 5 & 40 \\
$\%$ & $15 \%$ & $55 \%$ & $18 \%$ & $13 \%$ & $100 \%$ \\
\hline
\end{tabular}

Pátttakendur í spurningakönnuninni voru einnig spurðir að pví hverjir ættu að kjósa tilnefningarnefndina. Eins og sjá má á mynd 3, töldu 58\% pátttakenda að hluthafar ættu að kjósa hana á meðan aðeins $7 \%$ sögðu að hún ætti að vera kosin af stjórn. Alls tölu 22\% pátttakenda að hluthafar ættu að skipa meirihluta nefndarmanna en $10 \%$ völdu valmöguleikann „,annað“.

Mynd 3. Hverjir eiga að kjósa tilnefningarnefndarmenn?

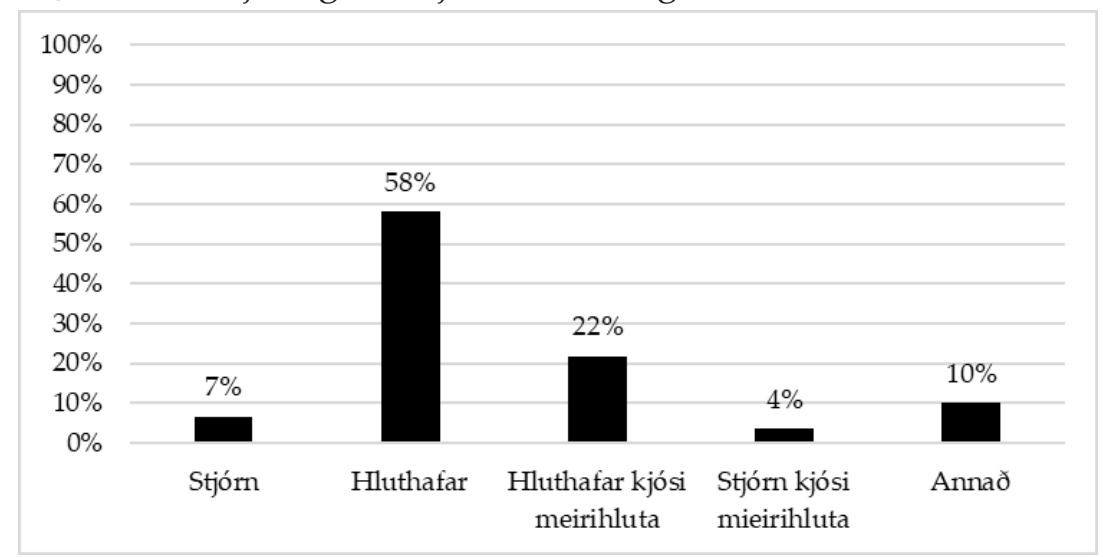




\subsection{Rök haghafa fyrir ólíkum leiðum}

Í íslenskum leiðbeiningum um stjórnarhætti er ekki tekið sérstaklega fram hvort tilnefningarnefndir eigi að vera skipaðar sem undirnefnd hluthafa eða undirnefnd stjórnar. Í leiðbeiningunum Viðskiptaráðs frá árinu 2015, er fyrst fjallað um tilnefningarnefndir í kaflanum um hluthafa og hluthafafund en í eldri leiðbeiningum var fjallað um nefndirnar í kaflanum um undirnefndir stjórnar (Viðskiptaráð Íslands o.fl., 2012). Ellefu af prettán viðmælendum höfðu skoðun á pví hvort tilnefningarnefndir ættu að vera undirnefnd hluthafa eða undirnefnd stjórnar, og gáfu fyrir pví ólík rök sem flokkuð eru og greint frá í premur undirköflum hér að neðan.

Skiptar skoðanir eru milli einstaklinga og haghafa á pessu málefni og voru prír viðmælendur sem höfðu orð á pví í viðtölunum. Einn viðmælandi hafði orð á pví að pað pyrfti að ákveða hvort nefndirnar eigi að heyra undir hluthafa eða vera undirnefnd stjórnar á meðan annar viðmælandi taldi pörf á að leyfa mismunandi aðferðir og leyfa tilnefningarnefndum pannig að próast. Mismunandi viðhorfum og rökum verður gerð skil í premur undirköflum hér að neðan og dregin saman og birt í töflu 7.

Tafla 7. Hluthafanefnd eða undirnefnd stjórnar, rök (svör) viðmælenda.

\begin{tabular}{|c|c|c|c|c|}
\hline Viðmælandi & $\begin{array}{l}\text { Hluthafanefnd eða undir- } \\
\text { nefnd stjórnar }\end{array}$ & $\begin{array}{l}\text { Kosin af hluthöfum eða } \\
\text { starfar í págu hluthafa }\end{array}$ & Óhád nefnd & Eftirlit með nefnd \\
\hline 1.T & \multicolumn{4}{|c|}{ Viðmælandi svaraði ekki hvort tilnefningarnefnd ætti að heyra undir hluthafa eða stjórn } \\
\hline 2.T & Hluthafa & $\begin{array}{l}\text { Nefndin vinnur fyrir } \\
\text { hluthafa. } \\
\text { Starfar í umboði hluthafa }\end{array}$ & & \\
\hline 3.T & Hluthafa & & $\begin{array}{l}\text { Nefndin er hlutlaust } \\
\text { batterí }\end{array}$ & \\
\hline 4.T & Hluthafa & Kosin af hluthöfum & $\begin{array}{l}\text { Nefndin á ekki að purfa } \\
\text { að vera í samskiptum við } \\
\text { stjórn eða forstjóra }\end{array}$ & $\begin{array}{l}\text { Starfsreglur nefndar- } \\
\text { innar eiga að vera sam- } \\
\text { pykktar af hluthöfum }\end{array}$ \\
\hline 5.T & Hluthafa & $\begin{array}{l}\text { Kosin af hluthöfum og } \\
\text { hluthafar hafi mótandi } \\
\text { áhrif á nefndina }\end{array}$ & & \\
\hline 6.T & Hluthafa & $\begin{array}{l}\text { Hluthafar hafa ákvörð- } \\
\text { unarvald á aðalfundi }\end{array}$ & $\begin{array}{l}\text { Spurning um óhæði } \\
\text { nefndarinnar ef hún } \\
\text { heyrir undir stjórn. } \\
\text { Of nálægt stjórn ef } \\
\text { stjórnarnefnd }\end{array}$ & $\begin{array}{l}\text { Farsælla fyrirkomulag } \\
\text { að hún heyri undir aðal- } \\
\text { fund }\end{array}$ \\
\hline 7.T & Hluthafa & $\begin{array}{l}\text { Nefndin vinnur fyrir } \\
\text { hluthafa }\end{array}$ & $\begin{array}{l}\text { Skiptir miklu máli að } \\
\text { nefndin sé óhád, sér- } \\
\text { staklega ef hún er undir- } \\
\text { nefnd stjórnar }\end{array}$ & $\begin{array}{l}\text { Ef nefnd starfar í um- } \\
\text { boði stjórnar að pá er } \\
\text { hún sett undir stjórnina } \\
\text { að pá erum við komin í } \\
\text { eitthvað amerískt kerfi } \\
\text { sem er að færa völdin frá } \\
\text { hluthöfum og til stjórna }\end{array}$ \\
\hline 8.T-S & $\begin{array}{l}\text { Viðmælandi nefndi stutt- } \\
\text { lega pemað án pess að } \\
\text { gefa í ljós sína skoðun }\end{array}$ & & $\begin{array}{l}\text { Tilnefningarnefnd getur } \\
\text { verið óhád pó hún sé } \\
\text { tengd stjórn. Hluthafar } \\
\text { gætu sett petta á dagskrá } \\
\text { stjórnar að velja næstu } \\
\text { stjórn }\end{array}$ & \\
\hline 9.T-S & Stjórn & $\begin{array}{l}\text { Nefndin parf ekki að } \\
\text { vera hluthafanefnd pó } \\
\text { meirihluti nefndar- } \\
\text { manna sé kosin af hlut- } \\
\text { höfum }\end{array}$ & $\begin{array}{l}\text { Verður að vera tenging } \\
\text { við stjórn }\end{array}$ & $\begin{array}{l}\text { Verður að tryggja eftirlit } \\
\text { og umsjón með nefnd- } \\
\text { unum. Ekki rökrétt að } \\
\text { nefndin heyri undir hlut- } \\
\text { hafa pegar eftirlitið er í } \\
\text { höndum stjórnar. Stjórn } \\
\text { betur til pess fallin að } \\
\text { stýra vinnu nefndarinnar } \\
\text { en hluthafar }\end{array}$ \\
\hline
\end{tabular}




\begin{tabular}{|c|c|c|c|c|}
\hline Viðmælandi & $\begin{array}{l}\text { Hluthafanefnd eða undir- } \\
\text { nefnd stjórnar }\end{array}$ & $\begin{array}{l}\text { Kosin af hluthöfum eða } \\
\text { starfar í págu hluthafa }\end{array}$ & Óhád nefnd & Eftirlit með nefnd \\
\hline $10 . S$ & Hluthafa & $\begin{array}{l}\text { Petta er ákvörðun fyrir } \\
\text { hluthafa, petta er ekki } \\
\text { ákvörðun stjórnar }\end{array}$ & $\begin{array}{l}\text { Nefnd ætti ekki að hafa } \\
\text { annarra hagsmuni að } \\
\text { gæta }\end{array}$ & $\begin{array}{l}\text { Rökréttara að nefndin } \\
\text { heyri undir hluthafa í } \\
\text { íslensku stjórnkerfi }\end{array}$ \\
\hline 11.F & Stjórn & $\begin{array}{l}\text { Hluthafar kjósi meiri- } \\
\text { hluta nefndarmanna }\end{array}$ & $\begin{array}{l}\text { Verður að vera tenging } \\
\text { við stjórn til að tryggja } \\
\text { eftirlit með störfum } \\
\text { nefndarinnar }\end{array}$ & $\begin{array}{l}\text { Nær stjórninni par sem } \\
\text { hluthafarnir eru meira } \\
\text { „fljótandi afl“. }\end{array}$ \\
\hline 12.F & $\begin{array}{l}\text { Hlutlaus - en telur að } \\
\text { hluthafar eigi að hafa } \\
\text { eftirlit með nefndinni }\end{array}$ & & $\begin{array}{l}\text { Sjáum hvernig nefndir } \\
\text { próast }\end{array}$ & $\begin{array}{l}\text { Hluthafar verði að } \\
\text { tryggja að nefndin vinni } \\
\text { eftir starfsreglum }\end{array}$ \\
\hline 13.R & $\begin{array}{l}\text { Stjórn, en bæði getur } \\
\text { gengið }\end{array}$ & $\begin{array}{l}\text { Pó að nefndin sé undir- } \\
\text { nefnd stjórnar pá getur } \\
\text { hluthafafundur valið } \\
\text { nefndarmenn }\end{array}$ & $\begin{array}{l}\text { Hefur ekki skoðun á pví } \\
\text { hvort nefndin eigi að } \\
\text { vera óháð eða ekki }\end{array}$ & $\begin{array}{l}\text { Lítil hefð fyrir pví á } \\
\text { Íslandi að pað séu ein- } \\
\text { hverjar stjórnareiningar } \\
\text { aðrar en stjórnin sem } \\
\text { heyri beint undir hlut- } \\
\text { hafafund. } \\
\text { Geta tryggt eftirlit og } \\
\text { umsjón með nefndunum }\end{array}$ \\
\hline
\end{tabular}

\subsubsection{Nefndarmenn kosnir af hluthöfum á aðalfundi félags}

Samkvæmt viðmælendum er ein helsta ástæða pess að tilnefningarnefndir eiga að heyra undir hluthafa sú að tilnefningarnefnd í heild sinni er kosin af hluthöfum í hverju félagi á aðalfundi ár hvert og að hún starfi í págu hluthafa. Sex viðmælendur af 13 töldu að nefndin eigi að vera hluthafanefnd vegna pess að nefndarmenn eru kjörnir af hluthöfum eða hún starfi fyrir hönd hluthafa. Fimm af pessum sex voru tilnefningarnefndarmenn á meðan sá sjötti var stjórnarmaður. Prír aðrir viðmælendur voru sammála um að nefndin eigi að vera kosin af hluthöfum. Petta voru stjórnar- og tilnefningarnefndarmaður, ráðgjafi og fjárfestir en peir voru allir á peirri skoðun að nefndirnar ættu að heyra undir stjórn. Ef litið er til peirra viðmælenda sem eiga sæti í tilnefningarnefndum pá var samhljómur á meðal peirra, eins og sjá má í töflu 7 , um að best færi á pví að nefndin heyrði beint undir hluthafa. Tveir viðmælendur (4.T og 5.T), höfðu orð á pví að nefndin ætti að vera hluthafanefnd par sem nefndin er kosin af hluthöfum. Viðmælandi 5.T tók fram að nefndin ætti að vera kosin af hluthöfum, og hluthafar ættu að ráða og hafa mótandi áhrif á nefndina.

Viðmælandi 7.T var einnig staðfastur í pví að nefndin ætti að vera hluthafanefnd par sem nefndin starfar fyrir hluthafa og, hún eigi að vera ofar í stjórnskipulagi en stjórn og skilar tillögum beint til hluthafa en ekki til stjórnarinnar. Jafnframt kom fram í viðtölunum að nefndin eigi að vinna fyrir hluthafana, líkt og viðmælandi 6.T benti á að nefndin ætti að vera hluthafanefnd par sem hluthafar hefðu ákvörðunarvald á hluthafafundi. Viðmælandi 2.T sagði einnig að: „,eins og ég horfi á petta pá ... við erum að vinna fyrir hlutahafana mér finnst pað mjög mikilvægt".

Aðrir er tilnefningarnefnd voru pó ekki eins sammála um að nefndin ætti að heyra undir hluthafa. Viðmælandi $10 . S$ sem er stjórnarmaður var pó á sama máli og tilnefningarnefndarmenn og sagði: „mér finnst petta eigi að vera undir hluthöfum... petta er ákvörðun fyrir hluthafa petta er ekki ákvörðun stjórnar...". Viðmælendur 9.T-S og 11.F voru auk pess sammála pví að hluthafar eigi að kjósa meiri hluta nefndarmanna en viðmælandi 9.T-S sagði pó að pað pýði ekki að nefndin eigi að vera hluthafanefnd. Viðmælandi 13.R var sammála honum og sagði: „pað er auðvitað hægt að útfæra pannig pó að nefndin sé undirnefnd stjórnar pá má hins vegar alveg velja nefndarmenn af hluthafafundi“. Viðmælandi 9.T-S sagði jafnframt að

„... pegar tilnefningarnefndin var sett á fót pá var hluthöfum kynnt, að prátt fyrir að hún væri undirnefnd stjórnar pá ættu hluthafarnir að kjósa nefndina. Pá var jafnframt lofað að ferlið yrði gagnsætt og skipulagið end- 
urskoðað eftir pörfum. Hluthafarnir sampykktu petta fyrirkomulag prátt fyrir að einn nefndarmaður hafi haft ákveðnar spurningar um pað áður en hann sampykkti“.

\section{1..2 Óhæði tilnefningarnefnda gagnvart stjórn}

Næsti undirflokkur fjallar um óhæði tilnefningarnefndanna. Níu af prettán viðmælendum nefndu eitthvað varðandi óháðar nefndir í viðtölunum (sjá töflu 7). Niðurstöðurnar sína að meiri hluti peirra sem telja að nefndirnar eigi að vera hluthafanefnd par sem sjálfstæði nefndanna er mikilvægt, eru tilnefningarnefndarmenn. Viðmælandi 7.T sagði t.d. að óhæði nefndarinnar skipti miklu máli og pá sérstaklega ef að nefndin á að starfa sem undirnefnd. Viðmælandi 6.T var á sama máli: „ef pú ert að heyra undir stjórn að pá finnst mér pú vera kannski komin of nálægt... pú veist pað er spurning pá um petta óhæði sko“. Viðmælandi 3.T sagði að nefndin ætti að vera „hlutlaust batterí“. Samkvæmt viðmælanda 4.T parf að vera skýrt að nefndin á að vera óháð og undir hluthöfum: „,...nefndin er undir hluthöfum pannig pá purfa líka boðleiðir og annað að vera pannig að pað purfi ekki einhvern vegin að vera pú veist í samskiptum við annaðhvort stjórnina eða forstjóra....".

Er litið er til viðhorfa stjórnarmanna eins og sjá má í töflu 7 , hvort sem peir sitja einnig í tilnefningarnefnd eða ekki, pá er ekki samhljómur meðal peirra um pessi atriði, einn peirra telur nefndin geti ekki átt annarra hagsmuni að gæta og lét í ljós pá skoðun sína að nefndin eigi að heyra undir hluthafa. Viðmælandi 10.S sagði að nefndin ætti ekki að hafa hagsmuna að gæta nein staðar (10.S) en viðmælandi 8.T-S taldi að stjórnarmenn gætu verið jafn óháðir og tilnefningarnefndarmenn við val stjórnarmanna:

Раð er ekki eins og tilnefningarnefndirnar séu einhvern vegin alveg bara ný uppfinning á jörðinni að par séu óháðir fulltrúar... stjórnin er bara líka metnaðargjarnt fólk sem vill vel... og hluthafarnir gætu raun og veru alveg sett petta á dagskrá stjórnar... að koma með rökstudda tillögu.

Samkvæmt viðmælanda 13.R er starfar sem ráðgjafi er hins vegar of mikill áhersla lögð á óhæði tilnefningarnefndarinnar og að stjórnin geti ekki tekið pátt í pessu ferli. Prátt fyrir að ferlið hefði áður verið á herðum stjórnarinnar og í einhverjum tilfellum aðeins í verkahring stjórnarformanns pá varð pað ekki „alslæmt“. Fjárfestir 12.F var aftur á móti opinn fyrir mismunandi leiðum hvað petta varðar, hann sagðist ekki hafa skoðun á óhæði nefndarinnar, hann vilji leyfa nefndunum að próast og taka pátt í peirri próun.

\subsubsection{Eftirlit með tilnefningarnefndum}

Priðji og síðasti undirflokkurinn snýr að pví hvert sé rökrétt skipulag tilnefningarnefnda á Íslandi. Pegar viðmælandi 13.R var spurður hvort nefndin ætti að vera undirnefnd eða hluthafanefnd var svarið: “hvoru tveggja hægt en pað er lítil hefð fyrir pví á Íslandi að pað séu einhverjar stjórnareiningar aðrar en stjórnin sem heyri beint undir hluthafafund pannig að pað kannski svona passar ekki alveg kannski inn í okkar strúktúr". Hann sagði jafnframt að раð passaði betur í okkar kerfi, hvað varðar íslenskan hlutafélagarétt, að nefndirnar séu undirnefndir stjórnar heldur en að hún heyri beint undir hluthafa. Hluthafarnir fundi jafnvel aðeins einu sinni á ári og pað sé ekki vettvangur til pess að hafa virkt eftirlit með störfum nefndarinnar. Petta verður auðveldara ef nefndin heyrir beint undir stjórn. Viðmælandi 7.T var ósammála pessu og sagði: „ef að hún er að fara að starfa í umboði stjórnar að pá er hún sett undir stjórnina að pá erum við komin í eitthvað amerískt kerfi sem er að færa völdin frá hluthöfum og til stjórna...". Viðmælandi 10.S var sammála pví аð pað að nefndin sé hluthafanefnd sé rökréttara fyrirkomulag.

Viðmælandi 9.T-S var á pví að nefndin ætti að vera undirnefnd stjórnar og telur að pað sé ekki rökrétt að nefndin heyri undir hluthafa á meðan stjórnin hafa eftirlit með störfum hennar. Pegar nefndin er undirnefnd stjórnar pá getur stjórnin að auki falið henni ákveðin 
verkefni. Viðmælendur 9.T-S og 13.R eru sammála um að tilnefningarnefndir eigi að vera undirnefndir stjórnar til pess að geta tryggt eftirlit og umsjón með nefndunum. Viðmælandi 9.T-S sagði að sem stjórnarmaður pá teldi hann að nefndin ætti að vera undirnefnd stjórnar vegna pess að peir vissu ekki hver ætti annars að stýra vinnu nefndarinnar. Viðmælandi 13.R sagði jafnframt: " ef að petta er undirnefnd stjórnarinnar pá er pað ábyrgð stjórnarinnar að setja nefndinni starfsreglur... eða fela nefndinni að setja sér starfsreglur og eftir atvikum fara yfir pað." Hann telur jafnframt vera mikilvægt að pað sé eitthvað eftirlit með nefndunum: „,... аð vera með einhverja tilnefningarnefnd sem... er kosin af einhverjum á aðalfundi og svo... leikur hún lausum hala og setur sér sínar eigin reglur og ég veit ekki hvað ég veit ekki hvort pað er betra“. Fjárfestir (11.F) telur að nefndirnar eigi að vera undirnefnd stjórnar par sem hún ætti að vera nær stjórninni par sem hluthafarnir eru meira "fljótandi afl“".

Ef að tilnefningarnefndir eru undirnefndir stjórnar pá pýðir pað samkvæmt viðmælendum ekki að hún eigi aðeins að vera skipuð stjórnarmönnum. Viðmælendur 9.T-S, 11.F og 13.R, sem eru með mismunandi bakgrunn, nefndu petta í viðtölunum. Viðmælendur 11.F og 9.T-S töldu nauðsynlegt að pað væri einhver tenging við stjórnina og par af leiðandi eigi nefndin að vera undirnefnd stjórnar. Viðmælandi 11.F, sem er fulltrúi hluthafa, telur að pessi tengin sé nauðsynleg til pess að hægt sé að hafa eftirlit með störfum tilnefningarnefnda pví að hluthafarnir viti ekki hvernig starf nefndanna gengur. Prátt fyrir að viðmælandi 12.F telji að fyrirtæki eigi að geta valið hvort nefndin heyri undir hluthafa eða stjórn, pá eigi hluthafar að tryggja að nefndin „vinni eftir starfsreglum sem eru í lagi“. Viðmælandi 4.T sagði einnig að starfsreglur nefndarinnar ættu að vera sampykktar af hluthafafundi.

Pegar viðmælendur veltu sérstaklega fyrir sér mikilvægi pess að tilnefningarnefnd væri veitt aðhald og eftirlit, og að starfsreglur væru skýrar og peim framfylgt pá voru fleiri viðmælendur á pví að tilnefningarnefndir eigi að vera undirnefnd stjórnar í stað pess að heyra undir hluthafa. Meira eftirlit sé pannig með nefndinni og að stjórnin sé betur til pess fallin en hluthafar að hafa eftirlit með nefndinni. Hins vegar pegar litið var til annarra pátta eins og óhæði nefndarmanna frá stjórn og hverjir skipa nefndir pá hölluðust fleiri viðmælendur að pví að betur færi á pví að tilnefningarnefndir heyri beint undir hluthafafund en ekki stjórn.

Pegar undirflokkarnir prír eru pví teknir saman má sjá að mjög skiptar skoðanir eru á pví hvort tilnefningarnefndir eiga að heyra undir hluthafa eða vera undirnefnd stjórnar. Peir tilnefningarnefndarmenn sem rætt var við um petta efni voru allir sammála um að nefndin ætti að heyra undir hluthafa, fyrir utan pá viðmælendur sem einnig áttu sæti í stjórn. Annar tilnefningarnefndar- og stjórnarmaðurinn var á pví að nefndin átti að heyra undir stjórn. Sá viðmælandi sem aðeins á sæti í stjórn var hinsvegar sammála tilnefningarnefndarmeðlimum um að nefndin skuli heyra undir hluthafa. Peir tveir stofnanafjárfestar sem rætt var við eru aftur á móti ekki sammála hvað petta varðar á meðan ráðgjafinn var á pví að nefndin ætti frekar að heyra undir stjórn.

\section{Umræður og lokaorð}

Rannsóknin veitir yfirlit yfir viðhorf ólíkra haghafa til pess hvort tilnefningarnefndir á Íslandi eigi að vera skipaðar sem undirnefndir stjórna eða heyra beint undir hluthafa. Höfundar vita ekki til pess að fyrirkomulag og starf tilnefningarnefnda á Íslandi hafi fram til pessa verið rannsakað. Niðurstöðurnar varpa ljósi á pað að tilnefningarnefndir ættu að heyra undir hluthafa að mati meirihluta viðmælenda og svarenda í viðhorfskönnun, óháð haghópum. Pessi niðurstaða er ápekk peirri sem Carlsson (2007) og Lekvall (2014) draga fram. Enn fremur sýna niðurstöðurnar að hagaðilar vilja flestir að nefndarmenn í tilnefningarnefndum verði kosnir af hluthöfum, rétt eins og fram kemur í niðurstöðum rannsókna Carlsson og Lekvall.

Á Íslandi sem og á hinum Norðurlöndunum er stjórnháttarskipulag fyrirtækja í lang 
flestum tilfellum í samræmi við tveggja-prepa líkanið eða norræna líkanið. Hluthafar eru á efsta lagi og skipa stjórn sem síðan skipar og hefur eftirlit með framkvæmdastjórn (Lekvall, 2014; Thomsen og Conyon, 2019). Pegar tilnefningarnefnd er skipuð eru skiptar skoðanir á pví hvar nefndin á að eiga heima innan pessa skipulags, pað er hvort hún eigi heima undir hluthöfum eða stjórn. Ýmsar rannsóknir hafa sýnt að nefndin eigi að vera undirnefnd stjórnar (t.d., Appiah og Chizema, 2015; Carson, 2002; Kaczmarek o.fl., 2012; Ruigrok o.fl., 2006), á meðan rannsóknir á Norðurlöndunum hafa komist að peirri niðurstöðu að farsælla sé að tilnefningarnefnd heyri undir hluthafa (Carlsson, 2007; Lekvall, 2014). Niðurstöður pessarar rannsóknar á íslenskum aðstæðum fylgja norrænu niðurstöðunum. Niðurstöður úr spurningarkönnuninni voru nokkuð afdráttarlausar óháð haghópum, tilnefningarnefnd ætti að heyra undir hluthafa. Prátt fyrir að skiptar skoðanir séu meðal viðmælenda rannsóknarinnar var meirihluti peirra á pví að tilnefningarnefnd ætti að vera hluthafanefnd. Helstu rökin sem nefnd voru fyrir pví að nefndin ætti frekar að heyra undir stjórn fyrirtækis voru pau að stjórn geti betur haft eftirlit með störfum tilnefningarnefndar en hluthafar. Petta samræmist rannsókn Ruigrok o.fl. (2006) par sem fram kemur að pó að tilnefningarnefnd sé ekki stjórnarnefnd er hún tæknilega undirnefnd stjórnar par sem stjórn parf að sampykkja ákvarðanir nefndarinnar og hún hefur aldrei beint samband við hluthafa. Рað er pví ljóst að ef tilnefningarnefnd heyrir undir hluthafa, pá er æskilegt að eftirlit með henni sé tryggt, en nokkrir viðmælendur töldu að stjórn sé betur til pess fallin að sinna pví eftirliti en hluthafar.

Niðurstöður á viðhorfum ólíkra haghafa sýna að tilnefningarnefnd ætti að vera kosin af hluthöfum, í pað minnsta meirihluti nefndarmanna. Pó að meirihluti viðmælenda telji að раð pýði að tilnefningarnefnd eigi að vera undirnefnd hluthafa voru ekki allir sammála peirri skoðun. Í samanburði við önnur Norðurlönd eru nefndirnar í Noregi og Svípjóð kosnar af hluthöfum og heyra að auki undir pá (Sjöstrand o.fl., 2016). Lekvall (2014) komst aftur á móti að pví að ef tilnefningarnefndir eru undirnefndir stjórnar pá eigi pær að vera skipaðar stjórnarmönnum. Petta er í samræmi við pað sem íslensku tilnefningarnefndirnar tvær, sem eru skipaðar premur stjórnarmönnum, hafa gert, en pær eru báðar undirnefndir stjórnar. Petta fyrirkomulag er einnig við líði í Danmörku par sem nefndirnar eru undirnefndir stjórnar og kosnar af stjórn (Sjöstrand o.fl., 2016). Í Finnlandi hefur verið farið pannig að, að báðar leiðir eru færar, að tilnefningarnefnd sé undirnefnd stjórna eða hluthafa. Bæði sjónarmið sem fram koma á Íslandi gætu pannig fundið sér farveg, pó greinilegt er að flestir horfi til pess að tilnefningarnefnd sé nefnd hluthafa.

Niðurstöðurnar sýna enn fremur að samhljómur er meðal peirra sem sitja eingöngu í tilnefningarnefndum en eru ekki jafnframt stjórnarmenn í viðkomandi fyrirtæki, að tilnefningarnefndir skuli heyra undir hluthafa. Rök fyrir peirri skoðun eru helstar pær að tilnefningarnefndir eru kosnar af hluthöfum og pannig starfi pær fyrir hönd hluthafa. Pví geti nefndirnar ekki heyrt undir stjórn. Tilnefningarnefndarmenn upplifa sig almennt frekar vera að starfa í págu hluthafa en stjórnar.

Par sem tilnefningarnefndir á Íslandi eru frekar nýlegar veitir pessi rannsókn mikilvæga innsýn í pá gerjun sem á sér stað í skoðunum og upplifun ólíkra aðila á pví undir hverja nefndirnar eiga að heyra, en pað hefur ekki verið rannsakað áður á Íslandi. Helstu takmarkanir rannsóknarinnar eru að meðal viðmælenda er hátt hlutfall tilnefningarnefndarmanna. Er gögnum var aflað var áhersla að afla gagna um starfsemi nefndanna sem skýrir hærra hlutfall pessa hóps í viðmælendahópi. Niðurstöður sýna að meiri samhljómar er meðal skoðana tilnefningarnefndarmanna en annarra viðmælenda að nefndin eigi að heyra undir hluthafa. Skoðun hluthafa og stjórnarmanna er pó afdráttarlaus ef horft er til niðurstaðna spurningarkönnunarinnar en par telja 66\% hluthafa og 63\% stjórnarmanna að tilnefningarnefnd eigi að heyra undir hluthafa. Niðurstöður sýna pví að nefndin ætti frekar að heyra undir hluthafa en stjórn, að mati haghafa, pó skiptar skoðanir séu á pví meðal viðmælaenda í hópi hluthafa og stjórnarmanna.

Sé litið til framtíðar mætti rannsókn greina viðhorf til nefndanna og starfa peirra á 
breiðara sviði en hér er gert. Einnig mætti greina frekar ferli nefndanna sjálfra og hvernig pær starfa. Pá er enn fremur áhugavert að rannsaka hverjir eiga að sitja í tilnefningarnefndum, sérstaklega út frá pví hvort stjórnarmenn eigi að hafa par sæti eða ekki. Mjög áhugavert væri að rannsaka reynslu peirra stjórnarmanna sem hafa sest í stjórnir eftir tilnefningu tilnefningarnefnda og bera saman við reynsla peirra sem voru skipaðir án aðkomu tilnefningarnefnda.

\section{Heimildir}

Appiah, K. O., og Chizema, A. (2016). The impact of board quality and nomination committee on corporate bankruptcy. Advances in accounting, 35. 75-81. https://doi.org/10.1016/j.adiac.2016.02.004

Cadbury, S. A. (2000). The corporate governance agenda. Corporate Governance: An International Review, 8(1), 7-15. https://doi.org/10.1111/1467-8683.00175

Carlsson, R. H. (2007). Swedish Corporate Governance and Value Creation: owners still in the driver's seat. Corporate Governance: An International Review, 15(6), 1038-1055. https://doi.org/10.1111/j.1467-8683.2007.00629.x

Carson, E. (2002). Factors associated with the development of board sub-committees. Corporate Governance: An International Review, 10(1), 4-18. https://doi.org/10.1111/1467-8683.00263

Clune, R., Hermanson, D. R., Tompkins, J. G., og Ye, Z. (2014). The nominating committee process: A qualitative examination of board independence and formalization. Contemporary Accounting Research, 31(3), 748786. https://doi.org/10.1111/1911-3846.12044

Committee on Corporate Governance. (2019). Recommendations on Corporate Governance (Version 4). https:// corporategovernance.dk/sites/default/files/190911_recommendations_version_260819.pdf

Eimskipafélag Íslands hf. (2020, 26. mars). Rules of Procedure for the Nomination Committee. https://www.eimskip.com/media/2226/nomination-committee_rules-of-procedure.pdf

Eminet, A., og Guedri, Z. (2010). The role of nominating committees and director reputation in shaping the labor market for directors: An empirical assessment. Corporate Governance: An International Review, 18(6), 557-574. https://doi.org/10.1111/j.1467-8683.2010.00814.x

Friðrik Friðriksson. (2019, 27. mars). Tilnefningarnefndir i hlutafélögum. Vísir. https://www.visir. is/g/2019190329055

Guo, L., og Masulis, R. W. (2015). Board structure and monitoring: New evidence from CEO turnovers. The Review of Financial Studies, 28(10), 2770-2811. https://doi.org/10.1093/rfs/hhv038

Hildur Magnúsdóttir. (2020). The Development and Structure of Nomination Committees in Iceland. [Ótgefin meistararitgerð]. Háskóli Íslands.

Huse, M. (2007). Boards, governance and value creation: The human side of corporate governance. Cambridge University Press. https://doi.org/10.1017/cbo9780511611070

Hutchinson, M., Mack, J., og Plastow, K. (2015). Who selects the 'right'directors? An examination of the association between board selection, gender diversity and outcomes. Accounting E Finance, 55(4), 1071-1103. https://doi.org/10.1111/acfi.12082

Johnson, R.B., Onwuegbuzie, A.J., \& Turner, L.A. (2007). Toward a definition of mixed method research. Journal of Mixed Method Research, 1(2), 112-133.

Kaczmarek, S., Kimino, S., og Pye, A. (2012). Antecedents of board composition: The role of nomination committees. Corporate Governance: An International Review, 20(5), 474-489. https://doi.org/10.1111/j.14678683.2012.00913.x

Kaczmarek, S., og Nyuur, R. (2016). Review of the literature on board committees: taking stock and looking ahead. International Journal of Business Governance and Ethics, 11(2), 89. https://doi.org/10.1504/ijbge.2016.078200

Lekvall, P. (Ed.) (2014). The Nordic corporate governance model. SNS Förlag https://www.sns.se/wp-content/uploads/2016/07/the_nordic_corporate_governance_model_1.pdf

Marel. (2019, 5. desember). Rules of Procedure for the Nomination Committee of Marel hf. https://marel.com/media/67879/100-marel-nomination-committee-rop.pdf

Merriam, S. B. (2016). Qualitative Research - A guide to Design and Implementation (2nd ed.). San Franscisco: Jossey - Bass.

Millet-Reyes, B., og Zhao, R. (2010). A comparison between one-tier and two-tier board structures in France. Journal of International Financial Management \& Accounting, 21(3), 279-310. https://doi.org/10.1111/j.1467646x.2010.01042.x

OECD. (2015). G20/OECD Principles of Corporate Governance. OECD Publishing. http://dx.doi.org/10.1787/ 9789264236882-en

Ólafur Arinbjörn Sigurðsson. (e.d.). Bæklingur um tilnefningarnefndir. Logos

Páll Harðarson. (2019, 16. April). Tilnefningarnefndir: Ekki til að skapa virðulega ásýnd um fyrirfram gefna niðurstöðu . Kjarninn miðlar ehf. https://kjarninn.is/skodun/2019-04-16-tilnefningarnefndir-ekki-til-ad-skapa-virdulega-asynd-um-fyrirfram-gefna-nidurstodu/ 
Poulsen, T., Strand, T., og Thomsen, S. (2010). Voting Power and Shareholder Activism: A Study of Swedish Shareholder Meetings. Corporate Governance: An International Review, 18(4), 329-343. https://doi.org/10.1111/ j.1467-8683.2010.00811.x

Reeb, D., og Upadhyay, A. (2010). Subordinate board structures. Journal of Corporate Finance, 16(4), 469-486. https://doi.org/10.1016/j.jcorpfin.2010.04.005

Ruigrok, W., Peck, S., Tacheva, S., Greve, P., og Hu, Y. (2006). The determinants and effects of board nomination committees. Journal of Management E Governance, 10(2), 119-148. https://doi.org/10.1007/s10997-006-0001-3

Securities Market Association. (2020). Finnish Corporate Governance Code 2020. https:/ecgi.global/sites/default/ files/codes/documents/corporate-governance-code-2020.pdf

Shivdasani, A., og Yermack, D. (1999). CEO involvement in the selection of new board members: An empirical analysis. The journal of finance, 54(5), 1829-1853. https://doi.org/10.1111/0022-1082.00168

Sjöstrand, S-E., Berglund, T., Grönberg, L., Kallifatides, M., Poulfelt, F., Pöyry, S., og Sigurjonsson, O. (2016). Nordic Corporate Governance: An Extensive In-Depth Study of Corporate Governance and Board Practices in 36 Large Companies. Stockholm School of Economics Institute for Research.

Strauss, A. L., og Corbin, J. M. (1998). Basics of qualitative research - Grounded theory procedures and techniques (2nd edition). Sage Publications.

Swedish Corporate Governance Board. (2020). The Swedish Corporate Governance Code. http://www.bolagsstyrning.se/UserFiles/Koden/The_Swedish_Corporate_Governance_Code_1_January_2020.pdf

The Norwegian Corporate Governance Board (NCGB). (2018). The Norwegian Code of Practice for Corporate Governance (9th edition). https://nues.no/wp-content/uploads/2018/10/NUES_eng_web_okt2018_2.pdf

Thomsen, S., og Conyon, M. (2019). Corporate Governance and Board Decisions. Djøf Publishing.

Viðskiptaráð Íslands, Nasdaq Iceland og Samtök atvinnulífsins. (2021a). Stjórnarhættir fyrirtækja. Leiðbeiningar (6. útgáfa). https://leidbeiningar.is/wp-content/uploads/2021/06/Stjornarhaettir_fyrirtaekja_A5_IS_Vefur. pdf

Viðskiptaráð Íslands, Nasdaq Iceland, og Samtök atvinnulífsins. (e.d.). Hluthafar og hluthafafundur. http://leidbeiningar.is/itarefni/efnisbreytingar/hluthafar-og-hluthafafundur

Viðskiptaráð Íslands, Nasdaq Iceland, og Samtök atvinnulífsins. (2015). Corporate Governance Guidelines (5th edition). http://vi.is/\%C3\%BAtg\%C3\%A1fa/sk\%C3\%BDrslur/leidbeiningar_um_stjornarhaetti_fyrirtaekja. pdf

Viðskiptaráð Íslands, Nasdaq OMX Iceland hf. og Samtök atvinnulífsins. (2009). Stjórnarhættir fyrirtækja (3. útgáfard edition). https://www.vi.is/files/cg3lokaweb_886826181.pdf

Viðskiptaráð Íslands, Nasdaq OMX Iceland hf. og Samtök atvinnulífsins. (2012). Stjórnarhættir fyrirtækja (4. útgáfath edition). https://www.vi.is/files/2012.03.08-stjornarhaettir-net_127435363.pdf

Viðskiptaráð Íslands, Samtök atvinnulífsins og Nasdaq Iceland. (2021b). Tilgangur og ávinningur tilnefningarnefnda: Reynsla og próun á Íslandi og Norðurlöndunum. https://leidbeiningar.is/wp-content/uploads/2021/02/ VI_Fylgirit_Vefur.pdf

Zhang, Y. (2008). Information asymmetry and the dismissal of newly appointed CEOs: An empirical investigation. Strategic Management Journal, 29(8), 859-872. https://doi.org/10.1002/smj.689

Porsteinn Friðrik Halldórsson. (2019, 30. January). Nefndirnar fara eins og eldur í sinu um Kauphöllina. Vísir. https://www.visir.is/g/2019190139962 
